University of Nebraska - Lincoln

DigitalCommons@University of Nebraska - Lincoln

Publications from USDA-ARS / UNL Faculty

U.S. Department of Agriculture: Agricultural

Research Service, Lincoln, Nebraska

2013

\title{
Thirty-year tillage effects on crop yield and soil fertility indicators
}

Douglas Karlen

USDA-ARS, doug.karlen@ars.usda.gov

John L. Kovar

USDA-ARS, john.kovar@ars.usda.gov

Cynthia A. Cambardella

USDA-ARS, cindy.cambardella@ars.usda.gov

Thomas S. Colvin

USDA-ARS, oxfrdfrm@huxcomm.net

Follow this and additional works at: https://digitalcommons.unl.edu/usdaarsfacpub

Karlen, Douglas; Kovar, John L.; Cambardella, Cynthia A.; and Colvin, Thomas S., "Thirty-year tillage effects on crop yield and soil fertility indicators" (2013). Publications from USDA-ARS / UNL Faculty. 1632. https://digitalcommons.unl.edu/usdaarsfacpub/1632

This Article is brought to you for free and open access by the U.S. Department of Agriculture: Agricultural Research Service, Lincoln, Nebraska at DigitalCommons@University of Nebraska - Lincoln. It has been accepted for inclusion in Publications from USDA-ARS / UNL Faculty by an authorized administrator of DigitalCommons@University of Nebraska - Lincoln. 


\title{
Thirty-year tillage effects on crop yield and soil fertility indicators
}

\author{
Douglas L. Karlen $^{\mathrm{a}, *}$, John L. Kovar ${ }^{\mathrm{a}}$, Cynthia A. Cambardella ${ }^{\mathrm{a}}$, Thomas S. Colvin ${ }^{\mathrm{b}}$ \\ ${ }^{a}$ USDA-Agricultural Research Service (ARS), National Laboratory for Agriculture and the Environment (NLAE), 2110 University Boulevard, Ames, IA 50011-3120, United States \\ ${ }^{\mathrm{b}}$ USDA-ARS (retired), 55670 290th Street, Cambridge, IA 50046, United States
}

\section{A R T I C L E I N F O}

\section{Article history:}

Received 13 November 2012

Received in revised form 1 February 2013

Accepted 3 February 2013

\section{Keywords:}

Conservation agriculture

Maize

Soybean

Soil-test P and K

Plant nutrition

Tillage system economics

\begin{abstract}
A B S T R A C T
Long-term studies are crucial for quantifying tillage effects on productivity and soil fertility. Moldboard plow, chisel plow, spring disk, ridge-tillage, and no-tillage systems were evaluated after 32 years of a corn (Zea mays L.) and soybean [Glycine max (L.) Merr.] rotation and 27 years of continuous corn in central Iowa, U.S.A. Productivity was quantified using yield, while soil fertility status was evaluated by collecting four, $5-\mathrm{cm}$ diameter soil cores to a depth of $0.9 \mathrm{~m}$ from each treatment, dividing them into four depth increments (0-15-, 15-30-, 30-60-, and 60-90-cm), analyzing them for bulk density (BD), $\mathrm{NO}_{3}-\mathrm{N}, \mathrm{NH}_{4-}$ $\mathrm{N}$, electrical conductivity (EC), pH, Mehlich-3 extractable $\mathrm{P}, \mathrm{K}, \mathrm{Ca}, \mathrm{Mg}$ and DTPA-extractable $\mathrm{Cu}, \mathrm{Fe}, \mathrm{Mn}$, and $\mathrm{Zn}$, and interpreting the data using lowa State University (ISU) guidelines. Production costs for each tillage and cropping system were also computed. To account for genetic and agronomic changes during the 30-year study period, yields were examined for establishment, maintenance, and intensification/ recovery phases. Rotated corn yield averaged $8.6,8.8$, and $11.6 \mathrm{Mg} \mathrm{ha}^{-1}$ and soybean yield averaged 2.7, 3.2, and 3.4 $\mathrm{Mg} \mathrm{ha}^{-1}$, respectively, for each of the phases. Continuous corn from 1988 to 2006 averaged 7.5 and $10.1 \mathrm{Mg} \mathrm{ha}^{-1}$ for the maintenance and intensification/recovery phases, respectively. Fixed plus variable machinery costs for corn ranged from 233 to $354 \mathrm{USD} \mathrm{ha}^{-1}$, while for soybean they ranged from 194 to 280 USD ha $^{-1}$. Net returns to land, labor and management ranged from 233 to 269, 560 to 620, and 437 to 483 USD ha $^{-1}$ for continuous corn, rotated corn, and rotated soybean, respectively. Based on 9year (2003-2011) average grain prices and yields from this study, the corn-soybean rotation was twice as profitable as continuous corn. Soil-test $\mathrm{P}$ and $\mathrm{K}$ measurements, as well as calculated $\mathrm{P}$ and $\mathrm{K}$ removal, suggest that nutrient mining occurred during the course of this study. The soil-test data also indicate that further studies are needed regarding plant availability of subsoil $\mathrm{K}$ and its impact on fertilizer recommendations. Overall, we conclude that with good nutrient management and crop rotation, yield and soil fertility differences between no-tillage and more intensive tillage systems can be minimized and that no-till production can be profitable on glacial till derived soils.
\end{abstract}

Published by Elsevier B.V.

\section{Introduction}

Long-term tillage studies were advocated by Richter et al. (2007) as one way to improve the management of rapidly changing ecosystems. Such studies are also important for agricultural producers because as Coughenour and Chamala (2000) stated, replacing moldboard plowing with conservation- or no-tillage practices, is truly a "cultural" change driven by multiple factors including markets, weather cycles, biological changes (e.g. glyphosate resistant crops), agribusiness, and scientific advances. Toliver et al. (2012) evaluated several studies comparing crop yield with and without tillage, and also concluded that soil and climate

\footnotetext{
* Corresponding author. Tel.: +1 515294 3336; fax: +1 5152948125.

E-mail addresses: Doug.Karlen@ars.usda.gov (D.L. Karlen),

John.Kovar@ars.usda.gov (J.L. Kovar), Cindy.Cambardella@ars.usda.gov

(C.A. Cambardella), oxfrdfrm@huxcomm.net (T.S. Colvin).
}

factors can influence the risk and expected return that farmers may achieve by adopting less intensive tillage practices.

Tillage and/or cropping practices can affect many different soil properties and processes (Karlen et al., 2008, 2011; Stott et al., 2011). For example, soil-test $P$ and $K$ levels and especially their tendency for stratification in response to no-tillage (e.g. Holanda et al., 1998; Karlen et al., 2002; Rehm and Fixen, 1990; Shi et al., 2012) have been shown to significantly affect crop productivity.

Long-term studies are even more valuable if the measurement data are accompanied by the management records (Richter et al., 2007). Cultivar, seeding rate, planting and harvest dates, $\mathrm{N}, \mathrm{P}$, and $\mathrm{K}$ fertilizer applications, pesticide inputs and estimated costs of production for the different systems are frequently of interest to producers considering potential changes for their operations. Such details are also essential for those striving to develop economic, agronomic, and environmental assessment models (e.g. Six et al., 2004). Long-term field experiments are also crucial for addressing knowledge gaps that need to be filled to ensure long-term 
sustainability of alternate crop production enterprises (Toliver et al., 2012).

Our objective for this report is to summarize crop yield, soil fertility, and economic response data for five tillage systems evaluated from 1975 to 2006 on the Clarion-Nicollet-Webster/ Canisteo soil association in central Iowa, U.S.A. To facilitate comparisons during different phases of this 30-year field experiment, the response data were examined for three phasesestablishment (1976-1980), maintenance (1980-2002), and intensification/recovery (2003-2006).

\section{Methods and materials}

\subsection{Site characteristics and general experimental design}

This study was initiated at the Iowa State University (ISU) Agronomy/Ag Engineering Research and Education Center (AAEREC) in Boone County, IA (latitude $42^{\circ} 01^{\prime} \mathrm{N}$, longitude $93^{\circ} 45^{\prime} \mathrm{W}$ ) in 1975 . Three soil series (Canisteo [poorly and very poorly drained Typic Endoaquoll (map unit 507)], Clarion [well drained Typic Hapludolls (map unit 138B)], and Webster [poorly drained Typic Haplaquolls (map unit 107)]\} are found at the site. The soils are derived from glacial till (Soil Survey Staff, 2010) and have an elevation difference of approximately $7 \mathrm{~m}$ across the 10 ha area (Fig. 1). Initially eight "replicates" of each tillage system were established and managed in a corn and soybean rotation (4 replicates each). The tillage systems, imposed on plots that were $27.4 \mathrm{~m}$ wide by $91.4 \mathrm{~m}$ long, were: (1) slot plant on ridges which was eventually transitioned to a no-till operation; (2) Spring Disk; (3) Till plant (ridge tillage) where surface soil to a depth of $\sim 5-$ $8 \mathrm{~cm}$ is "thrown off" during planting and then the ridges are later rebuilt through cultivation; (4) Fall moldboard plowing; and (5) Fall chisel plowing. From 1976 to 1980, the four replicates in the south half (Field 70) and north half (Field 71) were managed in an alternating corn and soybean rotation. Starting in 1979 and continuing through 2006, the four replicates in Field 70 were used for continuous corn production, while Field 71 was maintained in the corn/soybean rotation with each crop occurring every other year.

\subsection{Cultural practices}

The five tillage systems were characterized as follows: (1) moldboard plow which was considered the "conventional" system when the study was initiated, and for which corn stalks were generally shredded and disk harrowed before plowing to a depth of approximately $20 \mathrm{~cm}$ in the fall. Either corn or soybean was planted the following spring after seedbed preparation with a tandem disk harrow and spike-tooth drag harrow; (2) chisel plow for which the land was chisel plowed to a depth of approximately $20 \mathrm{~cm}$ in the fall, after shredding the stalks if following corn. The chisel plow had twisted points spaced $38 \mathrm{~cm}$ apart. In the spring, the seedbed was prepared by one field cultivation before planting; (3) spring disk, for which the stalks were shredded if following corn, and the seedbed was prepared by disking one or two times with a tandem disk. The typical disk configuration consisted of 56cm blades, spaced $23 \mathrm{~cm}$ apart, and weighing approximately $57 \mathrm{~kg}$ blade $^{-1} ;$ (4) till-plant (ridge-till) for which no pre-plant tillage was used, although if the previous crop was corn, stalks were often shredded. Row attachments in front of the double-disk openers removed crop residue and a small amount of soil just before the seeds were planted. Ridges were then rebuilt during the cultivation

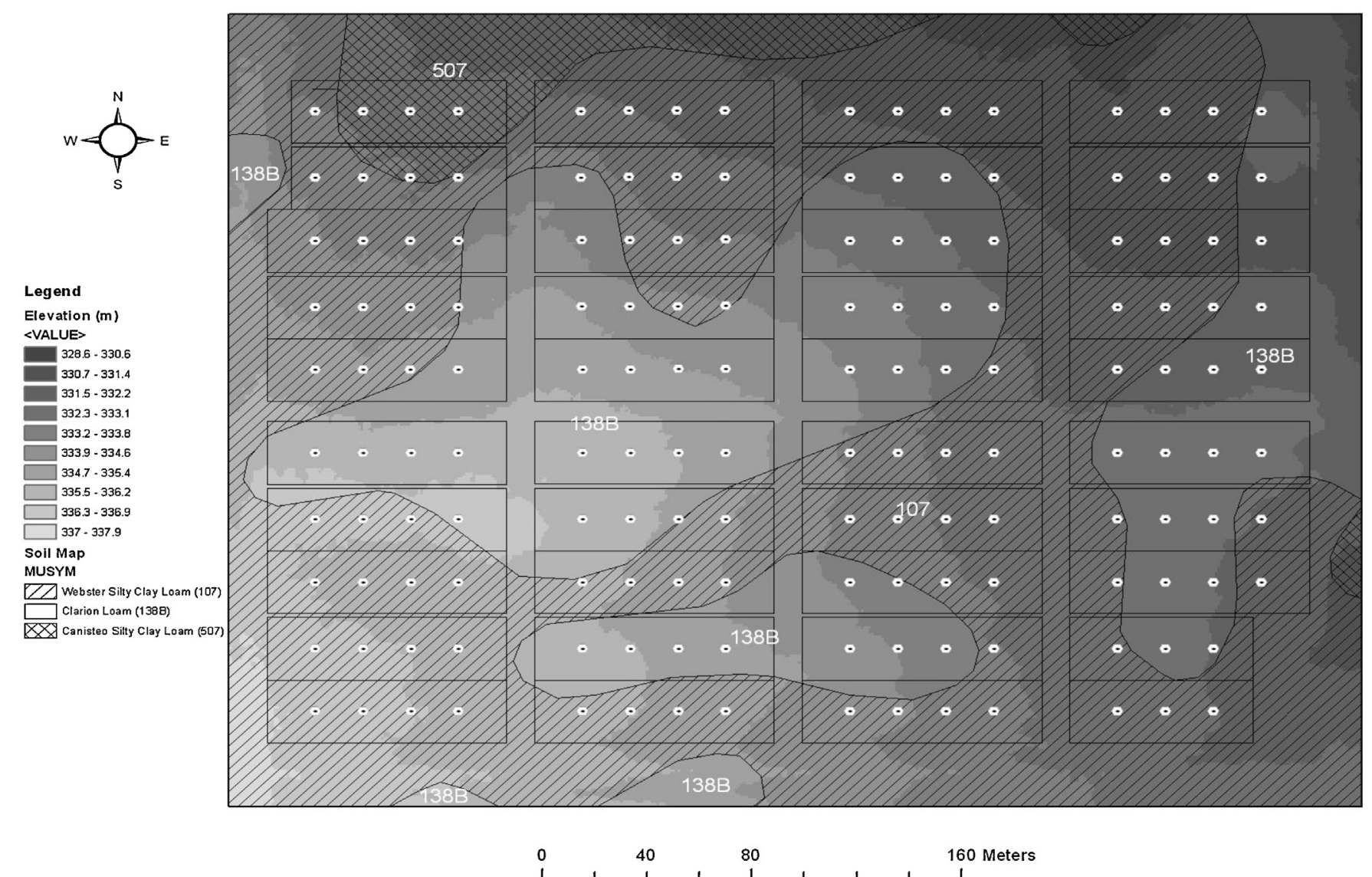

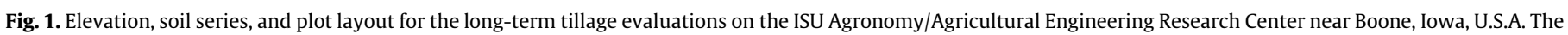
bottom half was in continuous corn from 1979 to 2006, while the top half was in a corn and soybean rotation. The points represent the 2005 soil sampling sites. 
process each year; and (5) slot-plant (no-tillage) for which there was no pre-plant tillage other than shredding the stalks if the previous crop was corn. The planter was equipped with a single coulter in front of double-disk openers. Small ridges that may have been built through cultivating during the previous season were left undisturbed. It should be noted that because of the longevity of this study, many subtle management changes were made as equipment and herbicide technologies improved. Prior to the mid1990 s, it was common for many no-till studies in central Iowa to be cultivated at least once for improved weed control. In some years it was also necessary to hand-weed the soybean plots for late-season weed control.

Commercially available corn and soybean cultivars (Table 1) were planted in $76 \mathrm{~cm}$ rows between late April and early June each year. The planting rate for corn gradually increased from 6.4 to 7.4 seeds $\mathrm{m}^{-2}\left(26,000-30,000\right.$ seeds acre $\left.{ }^{-1}\right)$ throughout the study period due to improved plant genetics and agronomic practices. The seeding rate for soybean varied much less averaging 44.1 seeds $\mathrm{m}^{-2} \quad\left(178,500\right.$ seeds acre $\left.{ }^{-1}\right)$. Monthly precipitation and average daily maximum and minimum temperatures at the AAEREC for 1986-2006 are presented in Tables A1 and A2. Seasonal rainfall (April through October) ranged from 356 to $1238 \mathrm{~mm}$ with an overall annual average of $682 \mathrm{~mm}$ (26.9 inches). These rainfall amounts as well as the mean monthly temperatures were consistent with those reported for the period 1951-1974 (USDA-SCS, 1981).

Fertilizer N, P, and $\mathrm{K}$ were applied at rates consistent with ISU recommendations (Table 1 ). No additional fertilizer was applied for the soybean crop, because throughout the study period and even now, it is assumed that the quantity of nutrients supplied to the corn crop will be sufficient for a subsequent soybean crop. Several different herbicides were used throughout the study period (Tables A3 and A4), each being applied at rates consistent with recommended management practices for its period of use.

\subsection{Crop yield and macro-nutrient balance measurements}

The long-term crop yield record was divided into segments defined as (1) establishment, (2) maintenance, and (3) recovery/ intensification phases. The establishment phase focused solely on the first five years and is a summary of the information reported by Erbach (1982). Unfortunately, yield records for 1981-1987 have been lost, so the maintenance phase in this report covers only the period from 1988 to 2002 . The recovery/intensification phase from 2003 to 2006 was so defined because of an increased use of soil testing and plant analysis to determine why grain yields (especially for continuous corn) had fallen below National Agricultural Statistics Service (NASS) County averages (USDANASS, 2012).

Throughout the entire period of record, corn and soybean were harvested each year with plot-scale combines and grain yields were recorded (Table A5). Grain weights were taken either directly on the combine when the machines were equipped with weigh tanks or by transferring the grain for each plot to weigh wagons. Grain samples from each plot were collected and analyzed to determine water content (Table A6). Grain yields were then adjusted to a constant water content of 130 or $155 \mathrm{~g} \mathrm{~kg}^{-1}$ for soybean or corn, respectively.

\subsection{Machinery operations and estimated costs}

The machine operations used to implement the five tillage systems are presented in Table 5 . The data were compiled by reviewing annual soil and crop management records for the research site and summarizing the operations according to the frequency that it occurred (e.g. 1-4 cultivations). For this evaluation, 2012 fixed (i.e. depreciation, interest, insurance, housing) and variable (i.e. fuel, oil, repairs) machinery costs (Duffy, 2012a) were used to estimate a cost per hectare for each operation. Total machinery costs were calculated by summing costs for each operation. Average seed and chemical costs for each of the cropping systems were taken from Duffy (2012a). Gross returns were computed by multiplying the average grain yields for 2003 through 2006 (the intensification and recovery phase of the study) by the 9-year average corn ( $145 \mathrm{USD} \mathrm{Mg}^{-1}$ ) or soybean (330 USD $\mathrm{Mg}^{-1}$ ) price (USDA-NASS, 2012). Net returns to land, labor, and management were calculated by subtracting the average machinery and seed/chemical costs for each tillage system from the gross returns.

\subsection{Soil profile sampling and analyses}

The long-term tillage effects on soil fertility indicators were assessed by collecting 5-cm diameter soil cores to a depth of $0.9 \mathrm{~m}$ following the 2005 grain harvest. With the exception of plots on the northwest and southeast corners of the 10 ha research site, where grass waterways resulted in slightly shorter plots (Fig. 1), each tillage plot was approximately $91 \mathrm{~m}$ long. A fixed sampling pattern was used, resulting in soil cores being taken 18-, 37-, 49-, and $73-\mathrm{m}$ from the west edge of each plot (Fig. 1). By overlaying the soil survey map (USDA-SCS, 1981), this sampling protocol enabled us to examine not only multiple points within each tillage plot, but also to identify the predominant soil series and thus determine if there were different tillage responses to the two dominant soils. Since the Canisteo silty clay loam differs from the Webster silty clay loam primarily by the presence of free calcium carbonate at the surface, samples for those two series were pooled for statistical analyses and compared with the Clarion loam that is located at slightly higher ( $\sim 2-3 \mathrm{~m}$ ) elevations (Fig. 1). This approach resulted in 61 sampling sites classified as Clarion loam and 97 classified as Webster/Canisteo silty clay loam.

Each core was divided into increments of 0-15-, 15-30-, 30-60, and 60-90-cm. Incremental samples were placed in plastic bags and stored on ice until they could be transported to the lab, where they were refrigerated at $4{ }^{\circ} \mathrm{C}$ until processing. Each field-moist sample was weighed and mixed before processing. A $100 \mathrm{~g}$ subsample was removed and dried at $105^{\circ} \mathrm{C}$ to determine soil water content. The field-moist weight was adjusted to a dry weight and divided by the volume associated with each sample to estimate bulk density (BD). The remaining field-moist soil sample was passed through an 8-mm screen, air-dried, and then crushed to pass a $2 \mathrm{~mm}$ sieve. Sub-samples from each depth increment were analyzed for soil $\mathrm{pH}$ and electrical conductivity (EC) using a $1: 1$ soil to water ratio as appropriate for the location (Watson and Brown, 1998; Whitney, 1998a,b). A second sub-sample was extracted with $2 \mathrm{M} \mathrm{KCl}$ and analyzed for ammonium $\left(\mathrm{NH}_{4}-\mathrm{N}\right)$ and nitrate $\left(\mathrm{NO}_{3}-\mathrm{N}\right)$ concentrations using flow injection analysis (Lachat QC 800; Loveland, CO). A third sub-sample was extracted with Mehlich-3 solution (Mehlich, 1984) and the concentrations of phosphorus (P), potassium (K), calcium (Ca), and magnesium (Mg) in the extracts were determined via inductively coupled plasmaatomic emission spectroscopy (ICP-AES). A fourth sub-sample was extracted with diethylene-triamine-pentaacetic acid (DTPA) as described by Whitney (1998b) and analyzed for $\mathrm{Cu}, \mathrm{Fe}, \mathrm{Mn}$, and $\mathrm{Zn}$ using the ICP-AES.

To calculate individual plot means using the four sampling sites per plot, data from each sample point (approximately $20 \mathrm{~m}$ apart) were used to create a 4-m surface using the ArcGIS (ESRI; Redlands, CA) spatial analyst tool spline with barriers. The field boundary was used as the barrier for the spline interpolation to ensure the plot values were constrained to the field area. The spline interpolation was used to make sure estimated values in the 
Table 1

Selected cultural practices for the 30-year tillage system comparison study in central Iowa, U.S.A..

\begin{tabular}{|c|c|c|c|c|c|c|c|}
\hline Year & Cultivar & $\begin{array}{l}\text { Planting } \\
\text { date }\end{array}$ & $\begin{array}{l}\text { Planting rate } \\
\text { (seeds } \mathrm{m}^{-2} \text { ) }\end{array}$ & Harvest date & $\mathrm{N}\left(\mathrm{kg} \mathrm{ha}^{-1}\right)$ & $\mathrm{P}\left(\mathrm{kgha}^{-1}\right)$ & $\mathrm{K}\left(\mathrm{kg} \mathrm{ha}^{-1}\right)$ \\
\hline \multicolumn{8}{|c|}{ Rotated corn (CS) } \\
\hline 1976 & Pioneer Brand 3382 & May 4 & 6.4 & October 11 & 140 & 49 & 93 \\
\hline 1977 & Funks 4449 & April 27 & 6.4 & October 10 & 168 & 49 & 93 \\
\hline 1978 & DeKalb XL64 & May 3 & 6.4 & October 2 & 168 & 49 & 93 \\
\hline 1979 & DeKalb XL64 & May 14-17 & 6.4 & October 25 & 179 & 49 & 93 \\
\hline 1981 & Pioneer Brand 3541 & May 6 & 6.5 & October 16 & 179 & 49 & 93 \\
\hline 1983 & Pioneer Brand 3529 & May 12 & 6.5 & October 17 & 179 & 25 & 56 \\
\hline 1985 & Pioneer Brand 3732 & May 7 & 6.4 & October 14 & 179 & 30 & 56 \\
\hline 1987 & Pioneer Brand 3732 & April 23 & 6.8 & September 22 & 179 & 30 & 93 \\
\hline 1989 & Pioneer Brand 3720 & May 8-10 & 6.8 & October 9 & 224 & 30 & 56 \\
\hline 1991 & Pioneer Brand 3732 & May 13 & 6.4 & October 22 & 189 & 30 & 56 \\
\hline 1993 & Pioneer Brand 3394 & May 18 & 6.9 & October 28 & 157 & 0 & 0 \\
\hline 1995 & Pioneer Brand 3394 & May 16 & 6.9 & October 27 & 84 & 0 & 0 \\
\hline 1997 & DeKalb 529SR & May 14 & 7.0 & October 21 & 174 & 4 & 5 \\
\hline 1999 & Pioneer Brand 33G26 & April 30 & 7.0 & November 5 & 163 & 0 & 0 \\
\hline 2001 & Pioneer Brand 33G26 & April 26 & 7.0 & November 6 & 179 & 0 & 0 \\
\hline 2003 & Pioneer Brand 35P17 & April 29 & 7.2 & October 31 & 213 & 20 & 37 \\
\hline 2005 & Fontenelle 5L381 & April 28 & 7.4 & October 27 & 202 & 9 & 28 \\
\hline \multicolumn{8}{|c|}{ Rotated soybean (SC) } \\
\hline 1976 & Corsoy & May 18 & 38.9 & September 28 & 0 & 0 & 0 \\
\hline 1977 & Corsoy & May 16 & 43.2 & October 5 & 0 & 0 & 0 \\
\hline 1978 & Corsoy & May $15-16$ & 45.3 & September 27 & 0 & 0 & 0 \\
\hline 1979 & Harcor & May 22-23 & 47.5 & October 2 & 0 & 0 & 0 \\
\hline 1980 & Harcor & May 15 & 47.5 & October 9 & 0 & 0 & 0 \\
\hline 1982 & Corsoy 79 & June 7 & 45.3 & & 0 & 0 & 0 \\
\hline 1984 & Corsoy 79 & May 31 & 45.3 & September 21 & 0 & 0 & 0 \\
\hline 1986 & Corsoy 79 & June 12 & 45.3 & October 16 & 0 & 0 & 0 \\
\hline 1988 & Corsoy 79 & May 17 & 43.2 & October 26 & 0 & 0 & 0 \\
\hline 1990 & Corsoy 79 & May 1 & 45.3 & September 28 & 0 & 0 & 0 \\
\hline 1992 & Corsoy 79 & May 13 & 43.2 & October 2 & 0 & 0 & 0 \\
\hline 1994 & Steine 2250 & May 12 & 40.4 & October 22 & 0 & 0 & 0 \\
\hline 1996 & Steine 2170 & June 8 & 43.1 & October 28 & 0 & 0 & 0 \\
\hline 1998 & Pioneer Brand 9294RR & May 11 & 45.0 & October 1 & 0 & 0 & 0 \\
\hline 2000 & Asgrow 2601 & May 5 & 43.2 & & 0 & 0 & 0 \\
\hline 2002 & Asgrow 2601 & May 20 & 43.2 & October 26 & 0 & 0 & 0 \\
\hline 2004 & Asgrow 2107 & May 7 & 44.5 & September 22 & 0 & 0 & 0 \\
\hline 2006 & Asgrow 2203 & May 9 & 44.5 & September 29 & 0 & 0 & 0 \\
\hline \multicolumn{8}{|c|}{ Continuous corn (CC) } \\
\hline 1980 & DeKalb XL64 & April 23-25 & 6.5 & October 9 & 179 & 49 & 93 \\
\hline 1981 & Pioneer Brand 3541 & May 6 & 6.5 & October 16 & 179 & 0 & 0 \\
\hline 1982 & Pioneer Brand 3529 & May 3 & 6.5 & October 12 & 179 & 0 & 0 \\
\hline 1983 & Pioneer Brand 3720 & May 11 & 6.5 & - & 179 & 25 & 56 \\
\hline 1984 & Pioneer Brand 3541 & May 17 & 6.5 & October 12 & 179 & 0 & 0 \\
\hline 1985 & Ames Best SX-37 & May 1 & 7.1 & October 14 & 179 & 0 & 0 \\
\hline 1986 & Pioneer Brand 3475 & May 20 & 6.5 & October 7 & 179 & 0 & 0 \\
\hline 1987 & Pioneer Brand 3720 & June 12 & 6.8 & October 19 & 179 & 30 & 93 \\
\hline 1988 & Pioneer Brand 3720 & April 30 & 6.8 & October 26 & 179 & 30 & 56 \\
\hline 1989 & Pioneer Brand 3720 & May 8 & 6.7 & October 18 & 224 & 30 & 56 \\
\hline 1990 & Pioneer Brand 3475 & April 30 & 6.8 & October 9 & 179 & 30 & 56 \\
\hline 1991 & Pioneer Brand 3379 & May 13 & 6.4 & October 21 & 191 & 30 & 56 \\
\hline 1992 & Pioneer Brand 3417 & May 8 & 7.0 & October 26 & 185 & 0 & 0 \\
\hline 1993 & Pioneer Brand 3417IR & May 17 & 6.9 & October 27 & 157 & 0 & 0 \\
\hline 1994 & Pioneer Brand 3417IR & May 3 & 6.9 & October 25 & 202 & 0 & 0 \\
\hline 1995 & Pioneer Brand 3394 & May 16 & 6.9 & October 26 & 84 & 0 & 0 \\
\hline 1996 & Pioneer Brand 3395IR & May 16 & 7.4 & October 28 & 261 & 0 & 0 \\
\hline 1997 & DeKalb 592SR & May 14 & 7.0 & October 17 & 201 & 5 & 4 \\
\hline 1998 & DeKalb 550RR & May 4 & 7.4 & October 19 & 202 & 0 & 0 \\
\hline 1999 & Pioneer Brand 33G26 & April 30 & 7.0 & November 4 & 206 & 0 & 0 \\
\hline 2000 & Asgrow RX686RR & April 26 & 7.7 & September 29 & 235 & 17 & 0 \\
\hline 2001 & Asgrow RX686RR & April 26 & 7.0 & November 3 & 225 & 1 & 0 \\
\hline 2002 & Pioneer Brand 35P17 & April 26 & 7.0 & November 8 & 196 & 0 & 0 \\
\hline 2003 & Fontanelle 7797RR & April 28 & 7.2 & October 30 & 220 & 24 & 38 \\
\hline 2004 & Fontanelle 7797RR & April 27 & 7.4 & October 6 & 202 & 0 & 0 \\
\hline 2005 & Fontanelle 5L381 & April 29 & 7.4 & October 24 & 202 & 9 & 28 \\
\hline 2006 & Fontanelle 6 K547 & April 27 & 7.4 & October 12 & 39 & 0 & 28 \\
\hline
\end{tabular}

interpolated cells would not exceed measured values within the core data. A total of 158 soil cores were taken from the 88 plots (Fig. 1), which is 1.8 soil cores per plot. The interpolated surface contained on average 70 interpolated cells per plot. Data summaries for the plots were created using zonal statistics in ArcGIS. The 4-m grided surface for each type of soil measurement was used to create summary statistics based on plot zones.

\subsection{Statistical analyses}

Crop data from the maintenance and recovery/intensification phases were analyzed separately for the continuous corn and rotated corn/soybean systems. The data were evaluated with the General Linear Model (GLM) procedure from the SAS software packages (SAS Institute, 1990) to determine seasonal, tillage 
treatment, replicate, and year by tillage interaction effects. Soil data were analyzed by depth increment and evaluated with the SAS GLM procedure to determine tillage system, soil series, replicate and tillage by soil interactions. If the ANOVA F statistic was significant at $P \leq 0.10$, least significant difference (LSD) values were calculated to separate crop and soil indicator means. More conservative statistical approaches could have been used, but since mean yields for the various tillage systems were not agronomically significant, we chose to provide a liberal interpretation of the subtle differences that this unique, long-term record provided to producers and other stakeholders.

\section{Results and discussion}

\subsection{Grain yield response to tillage and crop rotation}

Corn and soybean grain yields for this long-term study are shown in Fig. 2, and for potential modeling purposes also presented for the three phases [(1) establishment, (2) maintenance, and (3) recovery/intensification] in Table A5. As stated by Erbach (1982) and verified by the non-significant tillage system difference (Table A5), the establishment phase for this study showed that "growth and yield depressions that commonly occur with continuous corn grown by using conservation tillage systems were not observed when corn was grown following soybeans or when soybeans were grown following corn." Furthermore, except for the 1976 soybean crop, average grain yields during this phase at the AAEREC research site exceeded the Boone County average (USDA-NASS, 2012) for all five tillage systems (Table A5).

Starting in 1981, the south half (i.e. Field 70) of this AAEREC research site (Fig. 1) was switched to continuous corn production, while the north half remained in a corn/soybean rotation for the duration of this study. Although yields from 1981 to 1987 were measured, as evidenced by the harvest dates recorded in the management record (Table 1), the yield data have been lost. Therefore, it is not possible to determine how quickly the continuous corn yields began to fall below the NASS Boone County average (Fig. 2), but with the exception of 1990 and 1991, average yields for all five tillage systems were just equal to or less than the NASS values. For the 15 years of available data characterized as Phase 2, moldboard plowing increased the average continuous corn grain yield by $0.8-1.7 \mathrm{Mg} \mathrm{ha}^{-1}\left(13-27 \mathrm{bu} \mathrm{ac}^{-1}\right)$ when compared to the other tillage systems. Moldboard plowing also had the highest average grain yield for rotated corn (Table A5), but the differences among tillage systems were smaller ranging from 0.2 to 0.8 and averaging only $0.35 \mathrm{Mg} \mathrm{ha}^{-1}\left(5.6 \mathrm{bu} \mathrm{ac}^{-1}\right)$. The moldboard plow treatment also had significantly lower grain moisture at harvest (Table A6) than the other tillage treatments, presumably because the plants had emerged more uniformly, grown more rapidly and matured earlier (data not presented). Grain moisture for the rotated corn was not affected by tillage, presumably because seedling emergence and subsequent plant growth (data not presented) were similar for all five tillage systems.

Visual comparisons between tillage systems (Fig. 2) show that the moldboard plow treatment generally had the highest yield, but actual differences were quite small (Table A5). Fig. 2 also shows that continuous corn had a lower average yield and greater variation due to seasonal weather patterns (Tables A1 and A2). A more detailed comparison of the overall yield averages for the two cropping systems during Phase 2 shows that crop rotation increased grain yield an average $1.3 \mathrm{Mg} \mathrm{ha}^{-1}\left(21 \mathrm{bu} \mathrm{ac}^{-1}\right)$ compared to continuous corn production (Table A5). This $17 \%$ yield increase is consistent with previous reports (e.g. Karlen et al., 1994, 2006, 2011) and re-emphasizes Erbach's 1982 conclusion regarding the importance of crop rotation. Seasonal comparisons
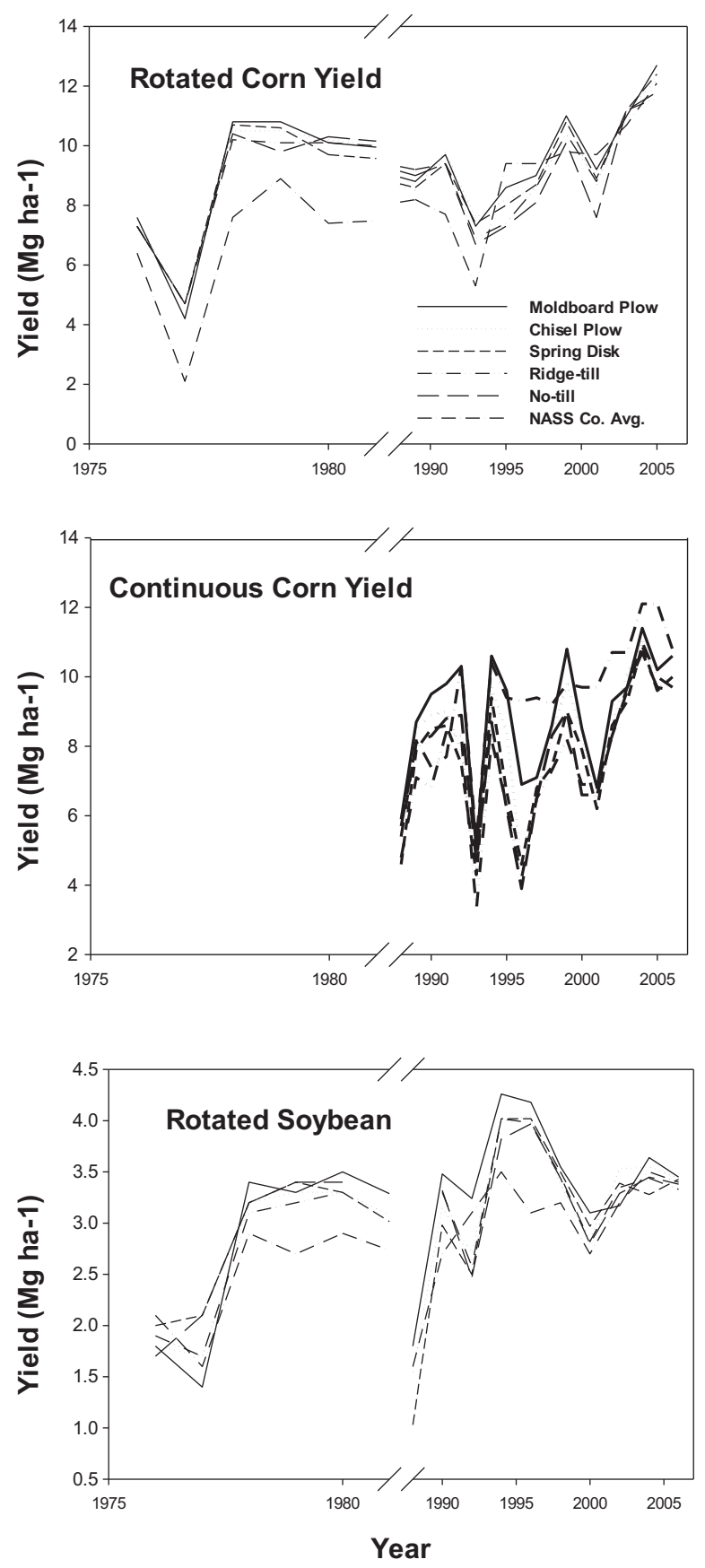

Fig. 2. Crop yield response to long-term tillage treatments on glacial till soils in Central Iowa, U.S.A.

between the NASS County averages and average yields for the five tillage systems showed that with rotation, yields were greater four times and less three times during this period of record (Table A5). Soybean yields during Phase 2 averaged $0.3 \mathrm{Mg} \mathrm{ha}^{-1}$ $\left(4.5 \mathrm{bu} \mathrm{ac}^{-1}\right.$ ) more than the average NASS value and were greater than the NASS values in 6 of 8 seasons. Among tillage systems, the chisel and disk tillage treatment yields were significantly lower than those of the other tillage treatments (Table A5), but the difference was quite small. Soybean grain moisture was relatively consistent, although there was a statistical difference between the disk- and ridge-tillage systems (Table A6) during Phase 2 of this long-term study.

Phase 3 (intensification and recovery) was differentiated from Phase 2 (maintenance) because the management intensity 
Table 2

Plant diagnostic analyses used to identify factors limiting ridge- and no-till corn production in a long-term study on glacial till soils in central Iowa, U.S.A.

\begin{tabular}{|c|c|c|c|c|c|c|c|c|c|c|c|}
\hline Tillage & $\mathrm{N}\left(\mathrm{g} \mathrm{kg}^{-1}\right)$ & $\mathrm{P}\left(\mathrm{g} \mathrm{kg}^{-1}\right)$ & $\mathrm{K}\left(\mathrm{g} \mathrm{kg}^{-1}\right)$ & $\mathrm{Ca}\left(\mathrm{g} \mathrm{kg}^{-1}\right)$ & $\operatorname{Mg}\left(\mathrm{g} \mathrm{kg}^{-1}\right)$ & $\mathrm{S}\left(\mu \mathrm{gg}^{-1}\right)$ & $\mathrm{B}\left(\mu \mathrm{gg}^{-1}\right)$ & $\mathrm{Cu}\left(\mu \mathrm{gg}^{-1}\right)$ & $\mathrm{Fe}\left(\mu \mathrm{gg}^{-1}\right)$ & $\operatorname{Mn}\left(\mu g g^{-1}\right)$ & $\mathrm{Zn}\left(\mu \mathrm{gg}^{-1}\right)$ \\
\hline \multicolumn{12}{|c|}{ Corn "Ear Leaf" analysis } \\
\hline Critical value & 27.5 & 2.5 & 17.0 & 2.0 & 2.0 & 1.0 & 5 & 3 & 20 & 20 & 25 \\
\hline \multicolumn{12}{|c|}{2003 Rotated corn } \\
\hline No-tillage & 28.2 & 2.5 & 10.3 & 6.0 & 3.6 & 1.51 & 5 & 10 & 160 & 30 & 14 \\
\hline Ridge-tillage & 27.8 & 2.6 & 9.5 & 6.2 & 3.8 & 1.59 & 5 & 10 & 161 & 36 & 15 \\
\hline $\operatorname{LSD}_{(0.1)}$ & NS & NS & 0.7 & NS & NS & 0.06 & NS & NS & NS & NS & NS \\
\hline \multicolumn{12}{|c|}{2004 Continuous corn } \\
\hline No-tillage & 27.8 & 3.0 & 16.4 & 8.1 & 4.0 & 1.7 & 7 & 9 & 98 & 71 & 21 \\
\hline Ridge-tillage & 28.0 & 3.1 & 15.5 & 8.8 & 4.5 & 1.7 & 7 & 9 & 99 & 68 & 22 \\
\hline $\operatorname{LSD}_{(0.1)}$ & NS & 0.1 & NS & 0.4 & 0.3 & NS & NS & NS & NS & NS & 1 \\
\hline \multicolumn{12}{|c|}{2005 Rotated corn } \\
\hline No-tillage & 27.5 & 2.7 & 13.5 & 6.8 & 4.6 & 1.5 & 8 & 11 & 139 & 58 & 18 \\
\hline Ridge-tillage & 27.7 & 2.9 & 12.9 & 7.6 & 5.2 & 1.6 & 9 & 11 & 135 & 65 & 19 \\
\hline $\operatorname{LSD}_{(0.1)}$ & NS & 0.2 & NS & 0.4 & 0.4 & NS & NS & NS & NS & NS & NS \\
\hline \multicolumn{12}{|c|}{2005 Continuous corn } \\
\hline No-tillage & 28.7 & 2.8 & 12.9 & 6.6 & 4.3 & 1.6 & 4 & 11 & 134 & 62 & 18 \\
\hline Ridge-tillage & 29.9 & 3.0 & 12.6 & 7.2 & 4.8 & 1.7 & 7 & 11 & 131 & 62 & 19 \\
\hline $\operatorname{LSD}_{(0.1)}$ & 0.5 & 0.1 & NS & 0.4 & 0.4 & 0.1 & 1 & NS & NS & NS & NS \\
\hline \multicolumn{12}{|c|}{2006 Continuous corn } \\
\hline No-tillage & 27.4 & 2.2 & 10.7 & 8.0 & 5.4 & 1.6 & 4 & 10 & 108 & 56 & 20 \\
\hline Ridge-tillage & 26.7 & 2.3 & 10.2 & 8.4 & 5.8 & 1.5 & 4 & 9 & 104 & 54 & 18 \\
\hline $\operatorname{LSD}_{(0.1)}$ & NS & NS & NS & NS & NS & NS & NS & 1 & NS & NS & 2 \\
\hline \multicolumn{12}{|c|}{ Corn V6 whole plant analysis } \\
\hline Critical value & 35.0 & 3.0 & 25.0 & 3.0 & 3.0 & 2.0 & 7 & 7 & 50 & 20 & 20 \\
\hline \multicolumn{12}{|c|}{2004 Continuous corn } \\
\hline No-tillage & 37.2 & 4.0 & 28.3 & 7.8 & 5.3 & 2.0 & 7 & 12 & 334 & 62 & 32 \\
\hline Ridge-tillage & 37.9 & 3.9 & 22.9 & 8.2 & 5.9 & 2.1 & 7 & 11 & 356 & 61 & 31 \\
\hline $\operatorname{LSD}_{(0.1)}$ & NS & NS & 2.2 & 0.3 & 0.3 & NS & NS & NS & NS & NS & NS \\
\hline \multicolumn{12}{|c|}{2005 Continuous corn } \\
\hline No-tillage & 37.4 & 4.4 & 18.7 & 6.8 & 5.0 & 2.3 & 7 & 11 & 475 & 54 & 43 \\
\hline Ridge-tillage & 38.6 & 4.4 & 16.4 & 7.5 & 5.3 & 2.3 & 7 & 11 & 510 & 55 & 44 \\
\hline $\operatorname{LSD}_{(0.1)}$ & NS & NS & 2.2 & 0.3 & NS & NS & NS & NS & NS & NS & NS \\
\hline \multicolumn{12}{|c|}{2005 Rotated corn } \\
\hline No-tillage & 42.4 & 4.1 & 28.6 & 7.4 & 5.0 & 2.2 & 8 & 13 & 749 & 65 & 43 \\
\hline Ridge-tillage & 41.8 & 4.2 & 20.7 & 8.1 & 5.8 & 2.3 & 9 & 13 & 1125 & 79 & 50 \\
\hline $\operatorname{LSD}_{(0.1)}$ & NS & NS & 4.1 & 0.4 & 0.5 & 0.1 & 0.4 & NS & 145 & 6 & 5 \\
\hline \multicolumn{12}{|c|}{2006 Continuous corn } \\
\hline No-tillage & 58.6 & 5.1 & 25.6 & 8.8 & 5.9 & 2.0 & 9 & 6 & 160 & 62 & 44 \\
\hline Ridge-tillage & 29.4 & 5.0 & 19.3 & 8.7 & 6.9 & 2.0 & 10 & 6 & 170 & 70 & 46 \\
\hline $\operatorname{LSD}_{(0.1)}$ & NS & NS & 3.1 & NS & 1.0 & NS & NS & NS & NS & NS & 2 \\
\hline
\end{tabular}

increased substantially through the use of yearly soil testing and plant tissue analyses. Preliminary investigations of the long-term management record (Colvin et al., 2001) had raised several questions regarding consistently lower yields under the ridgeand no-till systems, than under the moldboard plow system. Recognizing that soil fertility and/or plant nutritional differences could account for the "yield penalty" associated with continuous corn production, early season (V6) whole plant and leaf samples during pollination (R2) were collected from ridge- and no-till treatments during 2003-2006 (Table 2). The plant tissue samples indicated that during pollination, $\mathrm{K}$ concentrations were generally below the critical level (Mills and Jones, 1996), and therefore, K was likely one factor contributing to lower grain yields. These results differed from those of Shi et al. (2012), however, since V6 samples from ridge-till plots in both continuous and rotated corn production systems in 2004-2006 were always below the critical level $\left(25 \mathrm{~g} \mathrm{~kg}^{-1}\right)$, while with no-till, the $\mathrm{K}$ concentration at $\mathrm{V} 6$ was sufficient except for continuous corn in 2005. Samples collected from the moldboard plow treatments for both rotated $\left(16.8 \mathrm{~g} \mathrm{~kg}^{-1}\right)$ and continuous $\left(17.0 \mathrm{~g} \mathrm{~kg}^{-1}\right)$ corn ear-leaf $\mathrm{K}$ concentrations at pollination were also at or just below the critical level of $17.0 \mathrm{~g} \mathrm{~kg}^{-1}$ indicating that $\mathrm{K}$ fertilizer rates were probably insufficient for the higher plant populations (Table 1) and yield potential during the latter years of study (Table 3 ).

To complement the plant analysis data, soil-test data were also collected from the ridge- and no-tillage treatments in 2003 and 2004. Those samples (Table 4) indicated substantial stratification of both $\mathrm{P}$ and $\mathrm{K}$, with $\mathrm{K}$ values below $10 \mathrm{~cm}$ being classified as low or very low (Sawyer et al., 2011). According to the basic cation saturation ratio (BCSR) as described by Eckert (1987), K saturation in soil below a $5-\mathrm{cm}$ depth was less than the $2-5 \%$ suggested as being appropriate for Midwestern soils. This was consistent with other mid-Iowa studies on similar soils (Karlen et al., 2002). Based on this information, sub-plot studies focusing on $\mathrm{P}$ and $\mathrm{K}$ fertilizer placement (Karlen and Kovar, 2005) were conducted, and the rate of $\mathrm{P}$ and $\mathrm{K}$ fertilizer application for the overall tillage study was also increased (Table 1 ) during Phase 3.

Fertilizer N, P, and $\mathrm{K}$ application rates throughout the study averaged 174,25 , and $50 \mathrm{~kg} \mathrm{ha}^{-1} \mathrm{yr}^{-1}$ for rotated corn and 186, 10, and $21 \mathrm{~kg} \mathrm{ha}^{-1} \mathrm{yr}^{-1}$ for continuous corn. Therefore, to determine whether the macronutrient balance could explain why the average corn yields were at or below the NASS Boone County Average during Phases 2 and 3, when they had been 32\% higher during Phase 1 (Table 2 ), the crop grain yield data were multiplied by 
Table 3

Near-surface soil-test analyses used to help identify factors limiting ridge- and no-till corn production in a long-term study on glacial till soils in central Iowa, U.S.A.

\begin{tabular}{|c|c|c|c|c|c|c|}
\hline Depth $(\mathrm{cm})$ & Bulk density $\left(\mathrm{g} \mathrm{cm}^{-3}\right)$ & $\mathrm{pH}$ & Bray P $\left(\mathrm{mg} \mathrm{kg}^{-1}\right)$ & Exch. K & Exch. Ca & Exch. Mg \\
\hline \multicolumn{7}{|l|}{ Field 71-2003 } \\
\hline $0-5$ & 1.19 & 6.53 & 52 & 176 & 2916 & 392 \\
\hline $5-10$ & 1.24 & 6.61 & 29 & 96 & 2940 & 361 \\
\hline $10-20$ & 1.58 & 6.28 & 19 & 65 & 2899 & 392 \\
\hline $\operatorname{LSD}_{(0.1)}$ & 0.05 & 0.15 & 8 & 21 & NS & NS \\
\hline \multicolumn{7}{|l|}{ Field 71-2004 } \\
\hline $0-5$ & 1.16 & 6.56 & 43 & 192 & 3479 & 459 \\
\hline $5-10$ & 1.26 & 6.49 & 34 & 119 & 3667 & 439 \\
\hline $10-20$ & 1.42 & 6.32 & 17 & 107 & 3874 & 480 \\
\hline $\operatorname{LSD}_{(0.1)}$ & 0.14 & NS & 8 & 18 & NS & NS \\
\hline \multicolumn{7}{|l|}{ Field 70-2004 } \\
\hline $0-5$ & 1.15 & 6.24 & 50 & 199 & 3511 & 441 \\
\hline $5-10$ & 1.35 & 6.32 & 38 & 119 & 3258 & 399 \\
\hline $10-20$ & 1.42 & 6.16 & 14 & 83 & 3663 & 471 \\
\hline $\operatorname{LSD}_{(0.1)}$ & 0.13 & NS & 10 & 18 & NS & NS \\
\hline
\end{tabular}

Table 4

Machinery operations and 2012 estimated costs (U.S. \$ ha ${ }^{-1}$ ) for corn and soybean production using the five tillage systems evaluated in central Iowa U.S.A.

\begin{tabular}{|c|c|c|c|c|c|c|}
\hline Operation & $\begin{array}{l}\text { Unit } \\
\text { cost }\left(\$ h a^{-1}\right)\end{array}$ & $\begin{array}{l}\text { Moldboard } \\
\text { plow }\end{array}$ & $\begin{array}{l}\text { Chisel } \\
\text { plow }\end{array}$ & $\begin{array}{l}\text { Spring } \\
\text { disk }\end{array}$ & Ridge-Till & No-till \\
\hline \multicolumn{7}{|l|}{ Continuous $(C C)$ or rotated $(C S)$ corn } \\
\hline Chop stalks (CC only) & 26.68 & 26.68 & 26.68 & 26.68 & 26.68 & 26.68 \\
\hline Broadcast fertilizer & 8.75 & 8.75 & 8.75 & 8.75 & 8.75 & 8.75 \\
\hline Moldboard plow & 49.40 & 49.40 & & & & \\
\hline Chisel plow & 21.24 & & 21.24 & & & \\
\hline Tandem disk & 16.55 & $16.55-33.10$ & & $16.55-33.10$ & & \\
\hline Harrow & 9.63 & 9.63 & & 9.63 & & \\
\hline Field cultivate & 13.59 & & $13.59-27.18$ & & & \\
\hline Sprayer & 9.88 & 9.88 & 9.88 & 9.88 & 19.76 & 19.76 \\
\hline Planter & 28.16 & 28.16 & 28.16 & 28.16 & & \\
\hline No-till planter & 31.62 & & & & 31.62 & 31.62 \\
\hline Rotary hoe & 6.92 & 6.92 & 6.92 & 6.92 & & \\
\hline Cultivator & 10.13 & $10.13-20.26$ & $10.13-20.26$ & $10.13-20.26$ & $20.26-40.52$ & $20.26-30.39$ \\
\hline Sidedress fertilizer & 24.70 & 24.70 & 24.70 & 24.70 & 24.70 & 24.70 \\
\hline Combine & 79.04 & 79.04 & 79.04 & 79.04 & 79.04 & 79.04 \\
\hline Grain cart & 22.23 & 22.23 & 22.23 & 22.23 & 22.23 & 22.23 \\
\hline Grain hauling $^{\mathrm{a}}$ & $\left(0.0032 \mathrm{~kg}^{-1}\right)$ & 34.99 & 34.29 & 33.81 & 28.85 & 33.44 \\
\hline Total machine cost & & $327-354$ & 286-309 & $276-303$ & $262-282$ & $233-243$ \\
\hline Seed \& chemicals cost ${ }^{\mathrm{b}}$ & & 931 & 931 & 931 & 931 & 931 \\
\hline Gross return ${ }^{\mathrm{C}}$ continuous corn & & 1526 & 1482 & 1453 & 1467 & 1438 \\
\hline Net return ha ${ }^{-1}$ to land, labor, $\&$ management ${ }^{d}$ & & 255 & 254 & 233 & 264 & 269 \\
\hline Total machine cost & & $327-354$ & $286-309$ & $276-303$ & $262-282$ & $233-243$ \\
\hline Seed \& chemicals cost & & 813 & 813 & 813 & 813 & 813 \\
\hline Gross return rotated corn & & 1714 & 1700 & 1714 & 1656 & 1671 \\
\hline Net return ha ${ }^{-1}$ to land, labor, \& management & & 560 & 590 & 612 & 571 & 620 \\
\hline \multicolumn{7}{|l|}{ Rotated soybean (SC) } \\
\hline Chop corn stalks & 26.68 & 26.68 & 26.68 & 26.68 & 26.68 & 26.68 \\
\hline Moldboard plow & 49.40 & 49.40 & & & & \\
\hline Chisel plow & 21.24 & & 21.24 & & & \\
\hline Tandem disk & 16.55 & 33.10 & & 33.10 & & \\
\hline Harrow & 9.63 & 9.63 & & 9.63 & & \\
\hline Field cultivate & 13.59 & & $13.59-27.18$ & & & \\
\hline Sprayer & 9.88 & 9.88 & 9.88 & 9.88 & 19.76 & 19.76 \\
\hline Planter & 28.16 & 28.16 & 28.16 & 28.16 & & \\
\hline No-till planter & 31.62 & & & & 31.62 & 31.62 \\
\hline Rotary hoe & 6.92 & 6.92 & 6.92 & 6.92 & & \\
\hline Cultivator & 10.13 & $10.13-20.26$ & $10.13-20.26$ & $10.13-20.26$ & $20.26-40.52$ & $20.26-30.39$ \\
\hline Combine & 62.49 & 62.49 & 62.49 & 62.49 & 62.49 & 62.49 \\
\hline Grain cart & 22.23 & 22.23 & 22.23 & 22.23 & 22.23 & 22.23 \\
\hline Grain hauling $^{\mathrm{a}}$ & $\left(0.0032 \mathrm{~kg}^{-1}\right)$ & 11.33 & 11.17 & 10.75 & 10.88 & 10.94 \\
\hline Total machine cost & & $270-280$ & $212-236$ & $220-230$ & $194-214$ & $194-204$ \\
\hline Seed \& chemicals cost & & 447 & 447 & 447 & 447 & 447 \\
\hline Gross return soybean & & 1168 & 1152 & 1109 & 1122 & 1129 \\
\hline Net return ha ${ }^{-1}$ to land, labor \& management ${ }^{\mathrm{d}}$ & & 446 & 481 & 437 & 471 & 483 \\
\hline
\end{tabular}

${ }^{\text {a }}$ Grain hauling cost estimates are based on the average grain yield from Phase 4 of the study (2003-2006).

b From Duffy (2012a).

c Gross returns calculated by multiplying the average 2003-2006 yields from this study by the 9-year average prices given in NASS (2012).

d Net returns to land, labor, and management calculated by subtracting the average machinery costs plus the seed and chemical costs from the gross returns. 
estimates of $\mathrm{N}, \mathrm{P}$, and $\mathrm{K}$ content (IPNI; http://www.ipni.net/ nutrientremoval). The calculations showed that for continuous corn (1980-2006), N, P, and K removal accounted for 55, 234 and $155 \%$, respectively, of the applied fertilizer nutrients (Table 1 ). Similar calculations showed that nutrient removal from the rotation treatments during the corn phase alone accounted for 69,116 , and $77 \%$, respectively, of the applied nutrients. Estimated $\mathrm{N}$ removal during the soybean phase totaled $3463 \mathrm{~kg} \mathrm{ha}^{-1}$ which, by difference, indicates that at least $2556 \mathrm{~kg} \mathrm{ha}^{-1}$ had to come from fixation or residual total soil $\mathrm{N}$ supplies. With regard to $\mathrm{P}$ and $\mathrm{K}$, estimated removal via soybean seed totaled 337 and $983 \mathrm{~kg} \mathrm{ha}^{-1}$, respectively. Collectively $\mathrm{P}$ and $\mathrm{K}$ removal by both crops grown in the rotation treatment was almost twice (196 and 192\%, respectively) the level applied as fertilizer. Based on these calculations, there was indeed a high probability that nutrient mining created a yield limiting situation.

\subsection{Machinery operations, estimated costs, gross and net returns}

Machinery operations and estimated costs for each at 2012 prices (Duffy, 2012a) are summarized in Table 4. Estimates for seed and chemical input costs associated with each of the cropping systems from Duffy (2012a) are also presented. For continuous or rotated corn, average machinery costs for the five tillage systems ranged from 238 to 340 USD ha $^{-1}$, while for soybean following corn, they ranged from 199 to 275 USD ha $^{-1}$. As expected, the primary tillage costs and number of secondary tillage operations associated with each are the major factors accounting for differences between the tillage treatments.

Based on ISU Extension information (Duffy, 2012b), machinery costs during the course of this 30 -year study increased by approximately $250 \%$ for soybean and $275 \%$ for corn. This increase, however, was not the largest factor affecting overall costs of production as the cost for seed/chemicals/fertilizer and land costs increased by 358 and $447 \%$, respectively.

Net returns to land, labor and management ranged from 233 to 269,560 to 620 , and 437 to 483 USD ha $^{-1}$ for continuous corn, rotated corn, and rotated soybean, respectively. For all three cropping systems, net returns were higher for no-tillage than for the other tillage treatments. For rotated soybean, the smallest difference ( 2 USD ha ${ }^{-1}$ ) was noted for the comparison between the no-till and chisel plow treatments. Minimum tillage system differences for continuous and rotated corn were 5 and 9 USD ha $^{-1}$, respectively.

\subsection{Tillage and soil series effects on soil properties}

An analysis of variance by depth increment for the various soil properties [bulk density (BD), $\mathrm{NO}_{3}-\mathrm{N}, \mathrm{NH}_{4}-\mathrm{N}$, electrical conductivity (EC), pH, Mehlich-3 extractable P, K, Ca, Mg and DTPAextractable $\mathrm{Cu}, \mathrm{Fe}, \mathrm{Mn}$, and $\mathrm{Zn}$ ] measured to characterize long-term effects of five tillage systems and two crop rotations showed several statistically significant differences due to tillage system, soil series, and replicate, as well as several tillage by soil series interactions (Table A7). Differences among mean $\mathrm{pH}, \mathrm{P}$ and $\mathrm{K}$ values illustrate that although the differences are statistically significant, they are neither large nor of real agronomic importance (Table 5).

Collectively, these data show that soil pH in the top $15 \mathrm{~cm}$ and even into the $15-30 \mathrm{~cm}$ increment was beginning to drop to a level that could have an agronomic impact. According to the management records, agricultural lime was applied only once (1987) during the long-term study at a rate of $6.7 \mathrm{Mg} \mathrm{ha}^{-1}$ effective calcium carbonate. Acidification is generally not a major agronomic production issue for glacial-till derived soils in central Iowa, U.S.A. because of the calcareous subsoil below $60 \mathrm{~cm}$ (Table 5).
Table 5

Long-term tillage system and soil series effects on selected soil properties measured at four depth increments in soils derived from glacial till in central Iowa, U.S.A.

\begin{tabular}{|c|c|c|c|}
\hline Factor & $\mathrm{pH}$ & $\begin{array}{l}\text { Soil-test } \\
\mathrm{P}\left(\mu \mathrm{gg}^{-1}\right)\end{array}$ & $\begin{array}{l}\text { Soil-test } \\
\mathrm{K}\left(\mu \mathrm{gg}^{-1}\right)\end{array}$ \\
\hline \multicolumn{4}{|l|}{ Tillage system $(0-0.15 \mathrm{~m})$} \\
\hline Moldboard plow & 6.2 & 22 & 107 \\
\hline Chisel plow & 6.0 & 35 & 112 \\
\hline Spring disk & 6.1 & 33 & 125 \\
\hline Ridge-tillage & 6.2 & 31 & 115 \\
\hline No-tillage & 6.2 & 33 & 130 \\
\hline $\operatorname{LSD}_{(0.1)}$ & NS & 6 & 14 \\
\hline \multicolumn{4}{|l|}{ Tillage system $(0.15-0.30 \mathrm{~m})$} \\
\hline Moldboard plow & 6.3 & 14 & 104 \\
\hline Chisel plow & 5.9 & 11 & 97 \\
\hline Spring disk & 5.9 & 9 & 103 \\
\hline Ridge-tillage & 6.0 & 10 & 99 \\
\hline No-tillage & 6.1 & 12 & 105 \\
\hline $\operatorname{LSD}_{(0.1)}$ & 0.2 & 3 & NS \\
\hline \multicolumn{4}{|l|}{ Tillage system (0.3-0.6m) } \\
\hline Moldboard plow & 6.5 & 2 & 109 \\
\hline Chisel plow & 6.2 & 3 & 110 \\
\hline Spring disk & 6.3 & 4 & 114 \\
\hline Ridge-tillage & 6.4 & 3 & 114 \\
\hline No-tillage & 6.5 & 4 & 112 \\
\hline $\operatorname{LSD}_{(0.1)}$ & 0.2 & 1 & NS \\
\hline \multicolumn{4}{|l|}{ Tillage system (0.6-0.9 m) } \\
\hline Moldboard plow & 7.2 & 1 & 100 \\
\hline Chisel plow & 7.1 & 2 & 94 \\
\hline Spring disk & 6.9 & 2 & 101 \\
\hline Ridge-tillage & 7.0 & 2 & 103 \\
\hline No-tillage & 7.2 & 3 & 109 \\
\hline $\operatorname{LSD}_{(0.1)}$ & 0.2 & NS & NS \\
\hline \multicolumn{4}{|l|}{ Soil series $(0-0.15 \mathrm{~m})$} \\
\hline Clarion loam (138B) & 6.2 & 25 & 110 \\
\hline Webster (107) \& Canisteo (503) & 6.1 & 35 & 122 \\
\hline \multicolumn{4}{|l|}{ silty clay loam } \\
\hline $\operatorname{LSD}_{(0.1)}$ & NS & 4 & NS \\
\hline \multicolumn{4}{|l|}{ Soil series $(0.15-0.30 \mathrm{~m})$} \\
\hline Clarion loam (138B) & 6.0 & 11 & 95 \\
\hline $\begin{array}{l}\text { Webster (107) \& Canisteo (503) } \\
\text { silty clay loam }\end{array}$ & 6.1 & 12 & 106 \\
\hline $\operatorname{LSD}_{(0.1)}$ & NS & NS & 5 \\
\hline \multicolumn{4}{|l|}{ Soil series $(0.3-0.6 \mathrm{~m})$} \\
\hline Clarion loam (138B) & 6.3 & 4 & 104 \\
\hline $\begin{array}{l}\text { Webster (107) \& Canisteo (503) } \\
\text { silty clay loam }\end{array}$ & 6.5 & 3 & 117 \\
\hline $\operatorname{LSD}_{(0.1)}$ & 0.1 & 0.7 & 6 \\
\hline \multicolumn{4}{|l|}{ Soil series $(0.6-0.9 \mathrm{~m})$} \\
\hline Clarion loam (138B) & 7.0 & 2 & 96 \\
\hline $\begin{array}{l}\text { Webster (107) \& Canisteo (503) } \\
\text { silty clay loam }\end{array}$ & 7.1 & 2 & 105 \\
\hline $\operatorname{LSD}_{(0.1)}$ & NS & NS & NS \\
\hline
\end{tabular}

The spatial variability of soil-test $\mathrm{P}$ and $\mathrm{K}$ across the entire research site is illustrated in Figs. 3 and 4, respectively. The contour intervals for $\mathrm{K}$ are aligned with the ISU relative values used for soiltest $\mathrm{K}$ interpretation (Sawyer et al., 2011) and generally show higher levels in the Webster/Canisteo silty clay loam soils than in the Clarion loam. Areas with high levels in the surface are more likely to show higher concentrations in the lower depth increments, but there does not appear to be any pattern associated with the long-term tillage treatments. Subsoil soil-test P concentrations were so low that the contour interval for a "very low" ISU rating $\left(0-15 \mathrm{mg} \mathrm{kg}^{-1}\right)$ was split into two and the top interval included values that would be rated as both high and very high. The relatively low soil-test $P$ concentrations support the nutrient mining hypothesis based on crop yield and nutrient composition and also indicate that $\mathrm{P}$ levels certainly were not a potential environmental problem at this site. 


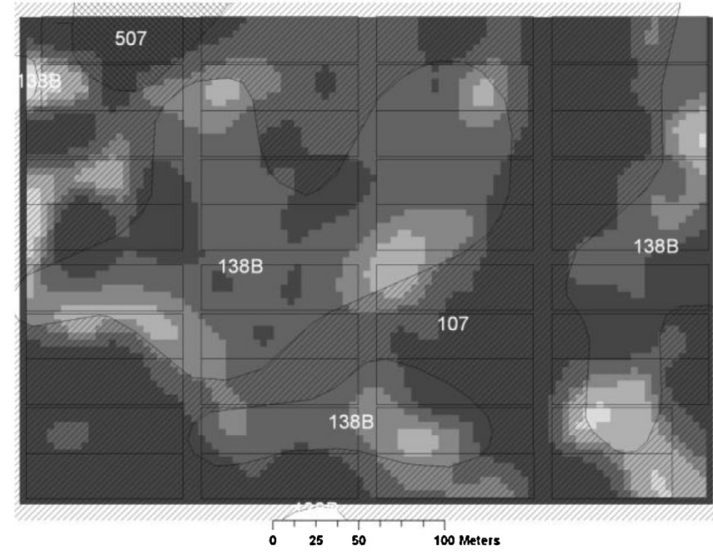

0 to $0.15 \mathrm{~m}$

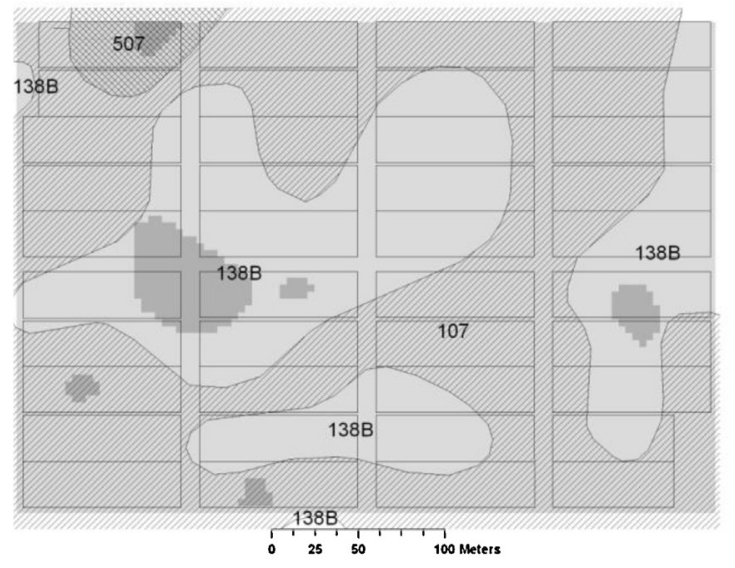

0.3 to $0.6 \mathrm{~m}$

Soil Test $P$ (mg/kg)

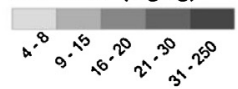

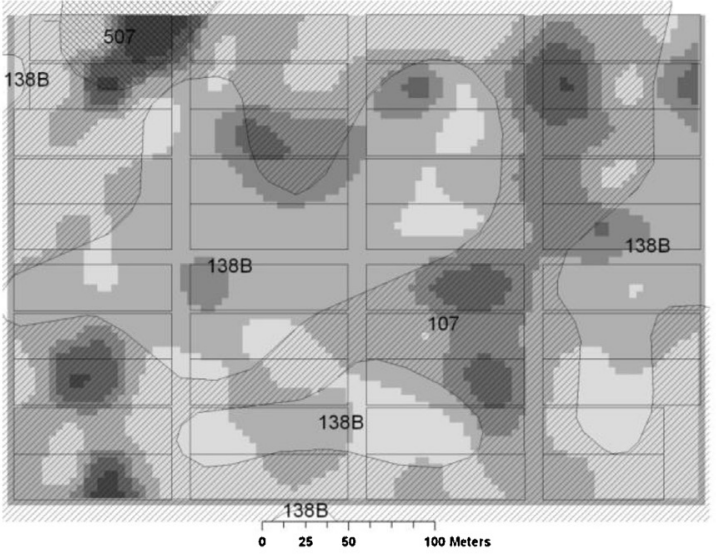

0.15 to $0.3 \mathrm{~m}$

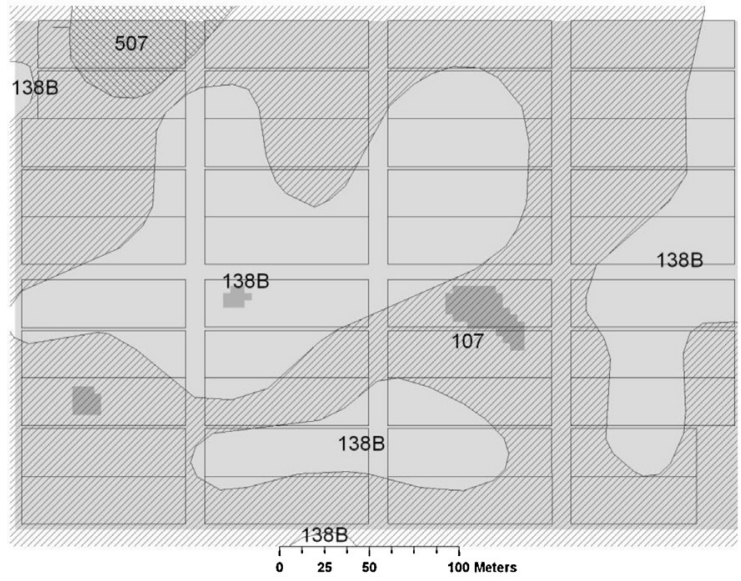

0.6 to $0.9 \mathrm{~m}$

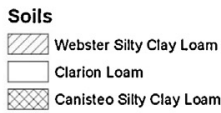

Fig. 3. Spatial variability of soil-test P after long-term tillage and cropping system evaluations on glacial-till derived soils in central Iowa, U.S.A.

Mean soil-test $\mathrm{P}$ and $\mathrm{K}$ concentrations at the various depth increments are also presented in Table 5. Among the five tillage systems, the moldboard plow treatment had a significantly lower surface $(0-15 \mathrm{~cm}) \mathrm{P}$ concentration than any other system. Conversely, within the $15-30 \mathrm{~cm}$ increment, soil-test $P$ was higher than for the other tillage treatments, presumably reflecting physical movement downward through the annual inversion process. Statistical differences were found within the 15-30- and $30-60-\mathrm{cm}$ increments, but all of the soil-test $P$ levels are considered very low (Sawyer et al., 2011), so there was really no agronomic difference among treatments. Comparing the two soil series shows that surface P levels in the Clarion loam were lower than for the Webster/Canisteo series. Soil-test P concentrations at the lower depth increments are all considered very low (Sawyer et al., 2011) and although there were some statistical differences, we do not consider them to be important from an agronomic perspective.

The plow treatment also had the lowest surface soil-test $\mathrm{K}$ concentration, but presumably due in part to spatial variability (Fig. 4), the average value was significantly different from only the disk and no-tillage treatments. There were no significant differences among tillage systems within the lower depth increments. Between the two soil series, $\mathrm{K}$ concentrations were always the lowest for the Clarion loam but the differences were statistically significant only for the 15-30-cm and 30-60-cm depth increments (Table 5).

The value of maintaining and collecting data from long-term soil and crop management studies is often debated, especially when human and fiscal resources become limited. A primary argument for doing so is the opportunity to examine the data for unanticipated questions. This study is no exception, especially since crop yield, nutrient applications, and estimated nutrient removal data can be combined with information from an intensive soil profile coring (Fig. 1) and subsequent soil sample analyses. For example, according to Sawyer et al. (2011), Clarion, Canisteo and Webster soils in central Iowa, U.S.A. generally have low subsoil $P$ $\left(\leq 8 \mu \mathrm{g} \mathrm{g}^{-1}\right.$ at the $76 \mathrm{~cm}$ depth) and low subsoil $\mathrm{K}\left(\leq 50 \mu \mathrm{g} \mathrm{g}^{-1}\right.$ at the 30-60 cm depth) levels. At this site, the low subsoil P status was confirmed, but subsoil $\mathrm{K}$ concentrations were nearly twice as high as the current value (i.e. $50 \mu \mathrm{g} \mathrm{g}^{-1}$ ) used to differentiate low and high subsoil $\mathrm{K}$ levels.

Having the correct classification (i.e. low or high subsoil concentrations) is important because subsoil $\mathrm{K}$ influences interpretation of surface $\mathrm{K}$ concentrations with regard to $\mathrm{K}$ fertilizer application rates (Sawyer et al., 2011). Assuming a low subsoil $\mathrm{K}$ rating, the surface soil-test $\mathrm{K}$ concentrations for all five tillage systems would be classified as low, but if subsoil $\mathrm{K}$ is classified as high, only the moldboard plow treatment would be classified as 


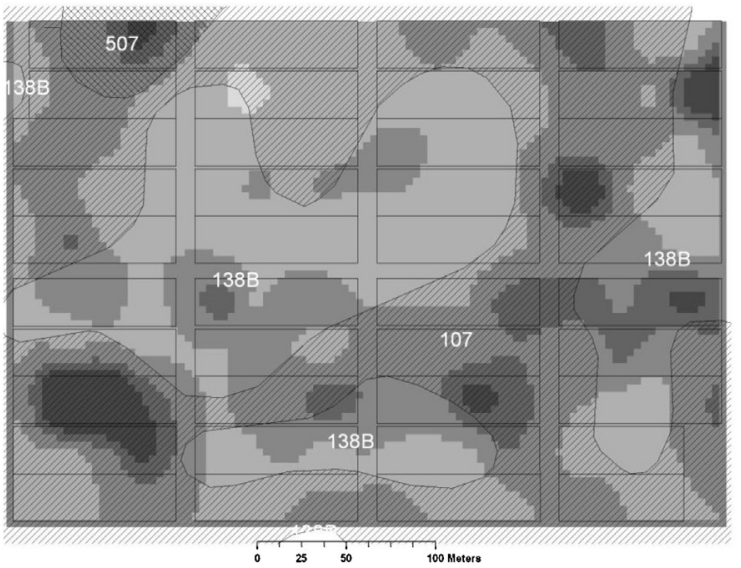

0 to $0.15 \mathrm{~m}$

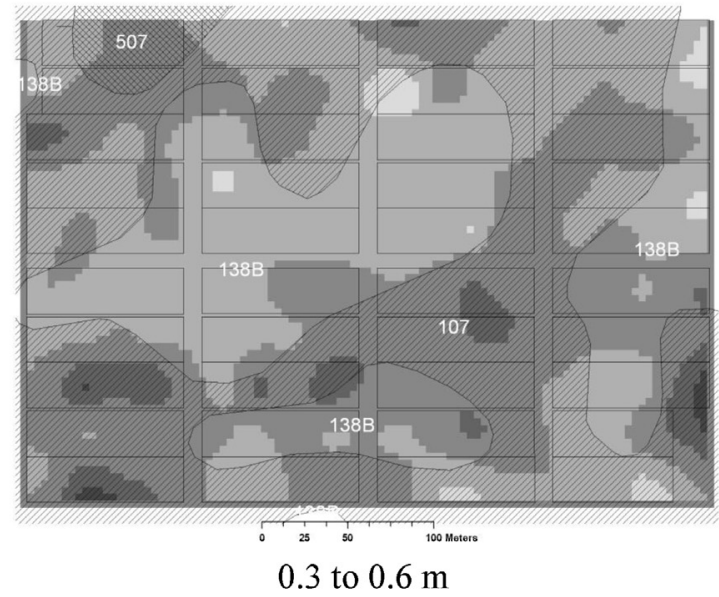

Soil Test $K$ (mg/kg)

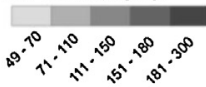

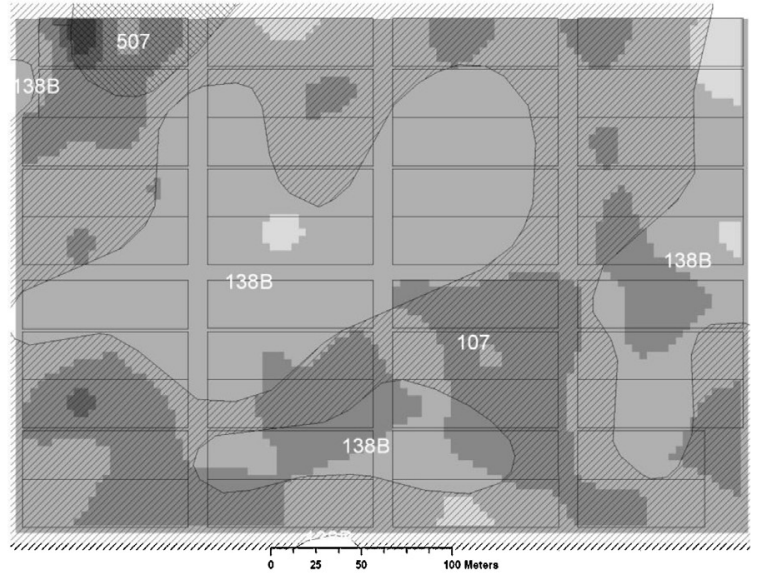

0.15 to $0.3 \mathrm{~m}$

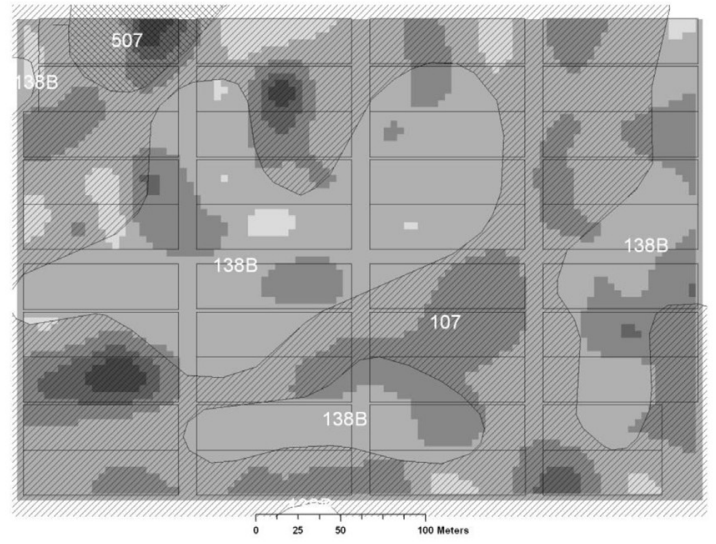

0.6 to $0.9 \mathrm{~m}$

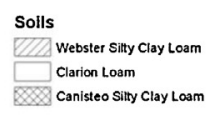

Fig. 4. Spatial variability of soil-test K after long-term tillage and cropping system evaluations on glacial-till derived soils in central Iowa, U.S.A.

low. The other four systems would be considered to have optimum soil-test $\mathrm{K}$. This soil-test interpretation dilemma is beyond the scope of this study, but because plant $\mathrm{K}$ concentrations were frequently below the critical level specified by Mills and Jones (1996) and because calculated K removal was twice the level applied through fertilization (Table 1), it is an issue that warrants further investigation on glacial till soils.

\section{Summary and conclusions}

Long-term evaluations of soil and crop production systems are essential for quantifying subtle effects of tillage and as a source of data for subsequent simulation modeling. This study examines 30year effects of five tillage systems used for a corn/soybean rotation or continuous corn production on glacial-till derived soils in central Iowa, U.S.A. Crop yields, estimated nutrient removal by grain harvest, machinery operations and costs, and changes in profile soil-test levels are reviewed. Appendices are also included to provide available rainfall, temperature, pesticide application, yield, and grain moisture data for those who may want to use this long-term record for model development and/or validation.

The analyses show that crop rotation increased corn grain yield by $17 \%$ compared to growing continuous corn. Calculated nutrient removal for continuous corn (1980-2006) accounted for 55, 234 and $155 \%$ of the applied fertilizer N, P, and K, respectively. Similar calculations for the rotated corn and soybean treatment indicated that almost twice as much P and K were removed (196 and 192\%, respectively) as had been applied as fertilizer. For continuous or rotated corn, average machinery costs for the five tillage systems ranged from 238 to 340 USD ha $^{-1}$, while for the rotated treatment, they ranged from 199 to 275 USD ha $^{-1}$. As expected, the major factor accounting for cost differences among the tillage treatments was the intensity of primary tillage and the number of secondary tillage operations needed to prepare the seedbed. Net returns to land, labor, and management for the no-till production were greater than for tilled systems even though actual grain yields were slightly lower. An intensive soil sampling and profile analysis after 29 years showed statistically significant tillage, soil series, replicate, and interactions between tillage and soil series, but numerically the differences were small and with the exception of $\mathrm{pH}, \mathrm{P}$ and $\mathrm{K}$ were of minimal agronomic importance. Soil $\mathrm{K}$ concentrations at the lower depth increments were "high" by current ISU soil-test interpretations, but until annual K fertilization rates were much greater than current recommendations based on the "high" subsoil rating, plant tissue analyses indicated plant available $\mathrm{K}$ was inadequate. This suggests further investigations are needed to improve soil-test $\mathrm{K}$ interpretations for glacial-till derived soils in central Iowa, U.S.A. Overall, we conclude that notillage can be successfully and profitably implemented on these soils by using improved nutrient management and crop rotation. 


\section{Acknowledgements}

Numerous USDA-ARS and Iowa State University (ISU) research support personnel have contributed to the care and maintenance of the plots and data associated with this long-term assessment. Without their dedication, this type of long-term, tillage system evaluation would not have been feasible.

\section{Appendix A}

See Tables A1-A7.

Table A1

Monthly rainfall (mm) at the AAEREC near Boone, Iowa, U.S.A.

\begin{tabular}{|c|c|c|c|c|c|c|c|c|}
\hline Year & April & May & June & July & August & September & October & Total \\
\hline 1986 & 99 & 127 & 172 & 130 & 85 & 164 & 120 & 897 \\
\hline 1987 & 54 & 86 & 68 & 125 & 308 & 44 & 28 & 713 \\
\hline 1988 & 36 & 38 & 140 & 340 & 59 & 335 & 27 & 975 \\
\hline 1989 & 251 & 397 & 337 & 58 & 40 & 82 & 73 & 1238 \\
\hline 1990 & 50 & 207 & 197 & 183 & 100 & 25 & 45 & 807 \\
\hline 1991 & 216 & 97 & 97 & 14 & 52 & 1 & 45 & 522 \\
\hline 1992 & 92 & 24 & 16 & 298 & 52 & 98 & 52 & 632 \\
\hline 1993 & 80 & 154 & 180 & 350 & 266 & 82 & 31 & 1143 \\
\hline 1994 & 65 & 42 & 144 & 80 & 77 & 104 & 75 & 587 \\
\hline 1995 & 0 & 0 & 67 & 109 & 70 & 61 & 49 & 356 \\
\hline 1996 & 31 & 191 & 120 & 97 & 119 & 79 & 69 & 706 \\
\hline 1997 & 78 & 56 & 91 & 94 & 31 & 57 & 12 & 419 \\
\hline 1998 & 68 & 96 & 249 & 64 & 80 & 25 & 88 & 670 \\
\hline 1999 & 191 & 134 & 171 & 146 & 144 & 53 & 8 & 847 \\
\hline 2000 & 26 & 106 & 101 & 67 & 31 & 23 & 42 & 396 \\
\hline 2001 & 85 & 159 & 42 & 43 & 64 & 134 & 57 & 584 \\
\hline 2002 & 86 & 112 & 71 & 134 & 118 & 32 & 70 & 623 \\
\hline 2003 & 81 & 113 & 134 & 159 & 32 & 87 & 21 & 627 \\
\hline 2004 & 60 & 179 & 81 & 43 & 115 & 30 & 36 & 544 \\
\hline 2005 & 58 & 106 & 115 & 97 & 163 & 93 & 3 & 635 \\
\hline 2006 & 58 & 58 & 13 & 80 & 59 & 90 & 53 & 411 \\
\hline Average & 84 & 118 & 124 & 129 & 98 & 81 & 48 & 682 \\
\hline
\end{tabular}

Table A2

Mean monthly temperatures $\left({ }^{\circ} \mathrm{C}\right)$ at AAEREC near Boone, Iowa, U.S.A.

\begin{tabular}{|c|c|c|c|c|c|c|c|c|c|c|c|c|c|c|}
\hline \multirow[t]{2}{*}{ Year } & \multicolumn{2}{|l|}{ April } & \multicolumn{2}{|l|}{ May } & \multicolumn{2}{|l|}{ June } & \multicolumn{2}{|l|}{ July } & \multicolumn{2}{|c|}{ August } & \multicolumn{2}{|c|}{ September } & \multicolumn{2}{|c|}{ October } \\
\hline & Min & Max & Min & Max & Min & Max & Min & Max & Min & Max & Min & Max & Min & $\operatorname{Max}$ \\
\hline 1986 & 5.2 & 18.2 & 10.8 & 22.7 & 16.1 & 28.0 & 18.5 & 30.4 & 14.0 & 25.8 & 13.3 & 24.3 & 5.2 & 16.6 \\
\hline 1987 & 4.7 & 20.4 & 12.1 & 26.4 & 15.8 & 30.0 & 18.6 & 30.7 & 14.8 & 26.5 & 10.7 & 24.5 & 1.6 & 15.6 \\
\hline 1988 & 2.2 & 18.2 & 13.2 & 27.1 & 20.8 & 28.2 & 23.2 & 31.9 & 22.6 & 31.3 & 16.4 & 23.4 & 7.2 & 14.0 \\
\hline 1989 & 3.1 & 18.1 & 8.8 & 23.7 & 15.4 & 27.0 & 18.3 & 30.1 & 16.7 & 28.2 & 9.9 & 23.1 & 4.3 & 18.5 \\
\hline 1990 & 2.2 & 15.8 & 8.8 & 19.8 & 17.0 & 27.0 & 18.4 & 27.7 & 19.0 & 29.2 & 13.8 & 26.1 & 3.6 & 17.6 \\
\hline 1991 & 6.0 & 17.7 & 15.2 & 26.4 & 18.6 & 28.6 & 18.2 & 29.6 & 18.0 & 27.9 & 10.6 & 24.1 & 3.7 & 17.5 \\
\hline 1992 & 2.4 & 13.2 & 9.1 & 22.4 & 14.2 & 26.9 & 15.4 & 24.2 & 13.1 & 24.2 & 10.0 & 22.7 & 3.9 & 17.1 \\
\hline 1993 & 2.5 & 13.4 & 10.6 & 20.4 & 14.8 & 24.9 & 17.1 & 28.9 & 16.4 & 30.3 & 9.1 & 23.9 & 3.9 & 17.4 \\
\hline 1994 & 3.0 & 16.2 & 9.9 & 23.1 & 15.8 & 27.0 & 15.8 & 27.6 & 14.6 & 26.6 & 11.9 & 25.3 & 6.9 & 17.7 \\
\hline 1995 & 1.5 & 12.3 & 8.6 & 17.9 & 15.5 & 25.5 & 17.4 & 27.3 & 19.0 & 30.0 & 9.2 & 23.2 & 4.8 & 16.6 \\
\hline 1996 & 1.3 & 16.4 & 9.4 & 19.0 & 16.0 & 27.1 & 16.0 & 27.2 & 16.0 & 26.8 & 10.2 & 22.0 & 4.2 & 17.4 \\
\hline 1997 & 0.8 & 13.5 & 7.0 & 20.2 & 15.8 & 28.4 & 17.4 & 29.0 & 15.8 & 26.8 & 11.8 & 25.2 & 5.9 & 17.3 \\
\hline 1998 & 4.9 & 15.2 & 12.5 & 24.7 & 14.5 & 24.4 & 18.1 & 28.7 & 18.2 & 27.8 & 13.5 & 27.4 & 6.4 & 17.0 \\
\hline 1999 & 4.7 & 15.0 & 10.8 & 21.0 & 15.8 & 25.5 & 19.8 & 30.6 & 16.0 & 26.6 & 8.9 & 23.0 & 3.2 & 18.0 \\
\hline 2000 & 2.7 & 17.2 & 10.8 & 24.2 & 14.1 & 25.8 & 17.2 & 27.4 & 17.1 & 28.4 & 10.9 & 26.1 & 6.8 & 18.9 \\
\hline 2001 & 5.0 & 18.6 & 10.9 & 21.1 & 15.2 & 26.8 & 18.8 & 29.5 & 17.0 & 28.1 & 10.4 & 22.3 & 4.0 & 16.3 \\
\hline 2002 & 2.9 & 15.3 & 7.6 & 20.9 & 16.8 & 28.3 & 18.6 & 30.1 & 15.7 & 27.0 & 11.9 & 25.5 & 2.0 & 12.5 \\
\hline 2003 & 4.0 & 16.4 & 9.2 & 20.4 & 14.0 & 25.6 & 17.0 & 28.0 & 16.9 & 28.8 & 8.9 & 22.9 & 4.4 & 18.7 \\
\hline 2004 & 3.5 & 17.8 & 10.4 & 21.9 & 13.6 & 24.7 & 16.0 & 26.2 & 13.1 & 24.2 & 12.1 & 26.6 & 5.3 & 16.5 \\
\hline 2005 & 5.7 & 18.3 & 8.5 & 20.5 & 16.6 & 28.0 & 17.3 & 29.0 & 15.6 & 27.4 & 12.6 & 26.8 & 4.3 & 18.0 \\
\hline 2006 & 5.6 & 18.4 & 10.6 & 22.1 & 15.8 & 27.7 & 18.4 & 29.8 & 17.3 & 27.1 & 9.9 & 21.6 & 3.4 & 14.3 \\
\hline Average & 3.5 & 16.5 & 10.2 & 22.2 & 15.8 & 26.9 & 17.9 & 28.8 & 16.5 & 27.6 & 11.2 & 24.3 & 4.5 & 16.8 \\
\hline
\end{tabular}

Table A3

Pesticide inputs over the course of a 30 -year tillage system comparison study in central Iowa, U.S.A.

\begin{tabular}{|c|c|c|c|c|}
\hline Year & Pesticide trade name ${ }^{a}$ & Applied to & Rate & Date \\
\hline \multicolumn{5}{|c|}{ Rotated corn (CS) } \\
\hline 1976 & Lasso & All & 4.6 $\mathrm{Lha}^{-1}$ & May 20 \\
\hline 1976 & Sencor & All & $0.4 \mathrm{~kg} \mathrm{ha}^{-1}$ & May 20 \\
\hline 1976 & Sevin & All & $2.3 \mathrm{Lha}^{-1}$ & May 21 \\
\hline
\end{tabular}


Table A3 (Continued)

\begin{tabular}{|c|c|c|c|c|}
\hline Year & Pesticide trade name ${ }^{\mathrm{a}}$ & Applied to & Rate & Date \\
\hline 1976 & Carbofuran & All & $1.1 \mathrm{~kg} \mathrm{ha}^{-1}$ & June 25 \\
\hline 1976 & Carbofuran & All & $1.1 \mathrm{~kg} \mathrm{ha}^{-1}$ & July 7 \\
\hline 1977 & Bladex & All & 4.6 $\mathrm{Lha}^{-1}$ & April 28 \\
\hline 1977 & Lasso & All & 4.6 $\mathrm{Lha}^{-1}$ & April 28 \\
\hline 1977 & Carbofuran & All & $1.1 \mathrm{~kg} \mathrm{ha}^{-1}$ & June 13 \\
\hline 1978 & Paraquot & Ridge-till \& No-till & $2.3 \mathrm{Lha}^{-1}$ & May 4 \\
\hline 1978 & Bladex & All & 4.6 $\mathrm{Lha}^{-1}$ & May 5 \\
\hline 1978 & Lasso & All & 4.6 $\mathrm{Lha}^{-1}$ & May 5 \\
\hline 1978 & $2-4-D$ & All & $1.2 \mathrm{Lha}^{-1}$ & June 2 \\
\hline 1978 & Carbofuran & All & $1.1 \mathrm{~kg} \mathrm{ha}^{-1}$ & June 19 \\
\hline 1978 & Carbofuran & Ridge-till & $1.1 \mathrm{~kg} \mathrm{ha}^{-1}$ & August 4 \\
\hline 1979 & Bladex & All & $4.6 \mathrm{Lha}^{-1}$ & May 17-21 \\
\hline 1979 & Lasso & All & $4.6 \mathrm{Lha}^{-1}$ & May $17-21$ \\
\hline 1979 & Paraquot & Ridge-till \& No-till & $2.3 \mathrm{Lha}^{-1}$ & May 17 \\
\hline 1979 & $2-4-D$ & All & $1.2 \mathrm{Lha}^{-1}$ & June 11 \\
\hline 1979 & Carbofuran & All & $1.1 \mathrm{~kg} \mathrm{ha}^{-1}$ & June 23 \\
\hline 1980 & Paraquot & No-till & $2.3 \mathrm{Lha}^{-1}$ & April 25 \\
\hline 1980 & Bladex & All & $4.6 \mathrm{Lha}^{-1}$ & April 25 \\
\hline 1980 & Lasso & All & 4.6 $\mathrm{Lha}^{-1}$ & April 25 \\
\hline 1980 & Atrazine + oil & No-till & $1.1 \mathrm{~kg}+2.3 \mathrm{Lha}^{-1}$ & May 20 \\
\hline 1980 & Basagran & Moldboard, Chisel, \& Disk & $2.3 \mathrm{Lha}^{-1}$ & May 23 \\
\hline 1980 & Carbofuran & Ridge-till \& No-till & $1.1 \mathrm{~kg} \mathrm{ha}^{-1}$ & June 17 \\
\hline 1981 & Glyphosate & Ridge-till \& No-till & $2.3 \mathrm{Lha}^{-1}$ & May 7 \\
\hline 1981 & Bladex & All & 4.6 $\mathrm{Lha}^{-1}$ & May 7 \\
\hline 1981 & Lasso & All & 4.6 $\mathrm{Lha}^{-1}$ & May 7 \\
\hline 1983 & Glyphosate & Ridge-till \& No-till & $2.3 \mathrm{Lha}^{-1}$ & May 13 \\
\hline 1983 & Bladex & All & $4.6 \mathrm{Lha}^{-1}$ & May 13 \\
\hline 1983 & Lasso & All & $4.6 \mathrm{Lha}^{-1}$ & May 13 \\
\hline 1983 & $2-4-D$ & All & $1.2 \mathrm{Lha}^{-1}$ & June 9 \\
\hline 1985 & Glyphosate & Ridge-till \& No-till & $2.3 \mathrm{Lha}^{-1}$ & May 6 \\
\hline 1985 & $2-4-D$ & Ridge-till \& No-till & $1.2 \mathrm{Lha}^{-1}$ & May 6 \\
\hline 1985 & Bladex & All & 4.6 $\mathrm{Lha}^{-1}$ & May 8 \\
\hline 1985 & Dual & All & $4.6 \mathrm{Lha}^{-1}$ & May 8 \\
\hline 1987 & No herbicides applied & - & - & - \\
\hline 1989 & Glyphosate & Ridge-till \& No-till & $2.3 \mathrm{Lha}^{-1}$ & May 8 \\
\hline 1989 & 2-4-D + crop oil & Ridge-till \& No-till & $1.2+2.3 \mathrm{Lha}^{-1}$ & May 8 \\
\hline 1989 & Bladex & All & 4.6 $\mathrm{Lha}^{-1}$ & May 8 \\
\hline 1989 & Lasso & All & $4.6 \mathrm{Lha}^{-1}$ & May 8 \\
\hline 1991 & Glyphosate & Ridge-till \& No-till & $2.3 \mathrm{Lha}^{-1}$ & May 13 \\
\hline 1991 & $2-4-\mathrm{D}+$ crop oil & Ridge-till \& No-till & $2.3+2.3 \mathrm{Lha}^{-1}$ & May 13 \\
\hline 1991 & Bladex 4L & All & 4. $6 \mathrm{Lha}^{-1}$ & May 13 \\
\hline 1991 & Lasso & All & 4.6 $\mathrm{Lha}^{-1}$ & May 13 \\
\hline 1991 & Buctril & (Spot sprayed) & $1.2 \mathrm{Lha}^{-1}$ & June 20 \\
\hline 1991 & Atrazine & (Spot sprayed) & $1.1 \mathrm{~kg} \mathrm{ha}^{-1}$ & June 20 \\
\hline 1991 & Accent & (Spot sprayed) & $49 \mathrm{mLha}^{-1}$ & June 20 \\
\hline 1993 & Glyphosate & Ridge-till \& No-till & $1.2 \mathrm{Lha}^{-1}$ & April 30 \\
\hline 1993 & $2-4-D+$ crop oil & Ridge-till \& No-till & $1.8+2.3 \mathrm{Lha}^{-1}$ & April 30 \\
\hline 1993 & Bladex 90 DF & All & $2.5 \mathrm{~kg} \mathrm{ha}^{-1}$ & May 18 \\
\hline 1993 & Lasso & All & 4. $6 \mathrm{Lha}^{-1}$ & May 18 \\
\hline 1993 & Glyphosate & Ridge-till \& No-till & $2.3 \mathrm{Lha}^{-1}$ & May 20 \\
\hline 1993 & $2-4-D+$ crop oil & Ridge-till \& No-till & $1.2+2.3 \mathrm{Lha}^{-1}$ & May 20 \\
\hline 1995 & Glyphosate & Ridge-till \& No-till & $2.3 \mathrm{Lha}^{-1}$ & May 12 \\
\hline 1995 & $2-4-D$ & Ridge-till \& No-till & $1.2 \mathrm{Lha}^{-1}$ & May 12 \\
\hline 1995 & Lasso & All & $7.0 \mathrm{Lha}^{-1}$ & May 16 \\
\hline 1995 & Accent & (spot treatment) & $49 \mathrm{~mL} \mathrm{ha}^{-1}$ & June 20 \\
\hline 1995 & Buctril & All & 1.2 $\mathrm{Lha}^{-1}$ & June 21 \\
\hline 1997 & Glyphosate & All & $2.3 \mathrm{Lha}^{-1}$ & May 17 \\
\hline 1997 & Poast Plus & All & $876 \mathrm{mLha}^{-1}$ & June 18 \\
\hline 1997 & Sencor & All & $36 \mathrm{mLha}^{-1}$ & June 20 \\
\hline 1997 & Buctril & All & $1.75 \mathrm{Lha}^{-1}$ & June 20 \\
\hline 1999 & Glyphosate & All & $2.3 \mathrm{Lha}^{-1}$ & April 28 \\
\hline 1999 & $2-4-D$ & All & 1.2 $\mathrm{Lha}^{-1}$ & April 28 \\
\hline 1999 & Balance & All & $150 \mathrm{mLha}^{-1}$ & April 30 \\
\hline 1999 & Sencor & All & $150 \mathrm{mLha}^{-1}$ & June 7 \\
\hline 1999 & Buctril & All & $0.6 \mathrm{Lha}^{-1}$ & June 7 \\
\hline 1999 & Accent & All & $24 \mathrm{~mL} \mathrm{ha}^{-1}$ & June 14 \\
\hline 2001 & Glyphosate & Ridge-till \& No-till & $2.3 \mathrm{Lha}^{-1}$ & April 30 \\
\hline 2001 & Dual Magnum & All & $1.8 \mathrm{Lha}^{-1}$ & April 30 \\
\hline 2001 & Buctril & All & $0.3 \mathrm{Lha}^{-1}$ & June 15-19 \\
\hline 2003 & Glyphosate & All & $1.9 \mathrm{Lha}^{-1}$ & April 29 \\
\hline 2003 & Dual II Magnum & All & $1.8 \mathrm{Lha}^{-1}$ & April 29 \\
\hline 2003 & Liberty & All & $2.0 \mathrm{Lha}^{-1}$ & June 16 \\
\hline 2005 & Lumax & All & $5.8 \mathrm{Lha}^{-1}$ & April 25-May 3 \\
\hline 2005 & Glyphosate & All & 1.6 $\mathrm{Lha}^{-1}$ & May 3 \\
\hline \multicolumn{5}{|c|}{ Rotated soybean (SC) } \\
\hline 1976 & Paraquot & Ridge-till & $1.8 \mathrm{Lha}^{-1}$ & May 21 \\
\hline 1977 & Paraquot & Ridge-till & $3.5 \mathrm{Lha}^{-1}$ & May 17 \\
\hline
\end{tabular}


Table A3 (Continued)

\begin{tabular}{|c|c|c|c|c|}
\hline Year & Pesticide trade name ${ }^{a}$ & Applied to & Rate & Date \\
\hline 1977 & Lasso & All & $4.6 \mathrm{Lha}^{-1}$ & May 18 \\
\hline 1977 & Amiben & All & $4.6 \mathrm{Lha}^{-1}$ & May 18 \\
\hline 1978 & Glyphosate & Ridge-till \& No-till & $4.6 \mathrm{Lha}^{-1}$ & May 15 \\
\hline 1978 & Lasso & All & 4.6 $\mathrm{Lha}^{-1}$ & May 17 \\
\hline 1978 & Sencor & All & $0.6 \mathrm{~kg} \mathrm{ha}^{-1}$ & May 17 \\
\hline 1978 & Basagran & All & $2.3 \mathrm{Lha}^{-1}$ & June 2 \\
\hline 1979 & Paraquot & Ridge-till \& No-till & $1.2 \mathrm{Lha}^{-1}$ & May 24 \\
\hline 1979 & Lasso & All & 4.6 $\mathrm{Lha}^{-1}$ & May 24 \\
\hline 1979 & Sencor & All & $0.6 \mathrm{~kg} \mathrm{ha}^{-1}$ & May 24 \\
\hline 1979 & Basagran & All & $2.3 \mathrm{Lha}^{-1}$ & June 15 \\
\hline 1980 & Glyphosate & No-till & $4.6 \mathrm{Lha}^{-1}$ & May 20 \\
\hline 1980 & Lasso & All & 4.6 $\mathrm{Lha}^{-1}$ & May 20-21 \\
\hline 1980 & Amiben & All & $4.6 \mathrm{Lha}^{-1}$ & May $20-21$ \\
\hline 1980 & Basagran & All & $2.3 \mathrm{Lha}^{-1}$ & June 17 \\
\hline 1980 & Hoelon & Moldboard \& Chisel Plow & $3.5 \mathrm{Lha}^{-1}$ & June 26 \\
\hline 1982 & Glyphosate & Ridge-till \& No-till & $2.3 \mathrm{Lha}^{-1}$ & June 7 \\
\hline 1982 & Lasso & All & $4.6 \mathrm{Lha}^{-1}$ & June $7-8$ \\
\hline 1982 & Amiben & All & $9.2 \mathrm{Lha}^{-1}$ & June $7-8$ \\
\hline 1982 & Hoelon & Ridge-till & $3.1 \mathrm{Lha}^{-1}$ & June 25 \\
\hline 1982 & Basagran & All & $2.3 \mathrm{Lha}^{-1}$ & June 28 \\
\hline 1982 & Carbofuran & Moldboard \& Chisel Plow & $1.1 \mathrm{~kg} \mathrm{ha}^{-1}$ & July 8 \\
\hline 1984 & Glyphosate & Ridge-till \& No-till & $2.3 \mathrm{Lha}^{-1}$ & May 18 \\
\hline 1984 & Lasso & All & $2.3 \mathrm{Lha}^{-1}$ & May 18 \\
\hline 1984 & Amiben & All & $9.2 \mathrm{Lha}^{-1}$ & May 18 \\
\hline 1984 & Basagran & All & $2.3 \mathrm{Lha}^{-1}$ & June 19 \\
\hline 1986 & Lasso & Ridge-till \& No-till & $5.8 \mathrm{Lha}^{-1}$ & April 24 \\
\hline 1986 & Amiben & Ridge-till \& No-till & $9.2 \mathrm{Lha}^{-1}$ & April 24 \\
\hline 1986 & Glyphosate & Ridge-till \& No-till & $2.3 \mathrm{Lha}^{-1}$ & June 12 \\
\hline 1986 & Dual & Ridge-till \& No-till & $2.3 \mathrm{Lha}^{-1}$ & June 12 \\
\hline 1986 & Amiben & Ridge-till \& No-till & $9.2 \mathrm{Lha}^{-1}$ & June 12 \\
\hline 1986 & Basagran & All & $2.3 \mathrm{Lha}^{-1}$ & July 3 \\
\hline 1988 & Glyphosate & Ridge-till \& No-till & $2.3 \mathrm{Lha}^{-1}$ & May 17 \\
\hline 1988 & Lasso & All & $2.3 \mathrm{Lha}^{-1}$ & May 17 \\
\hline 1988 & Amiben & All & $9.2 \mathrm{Lha}^{-1}$ & May 17 \\
\hline 1990 & Glyphosate & No-till & $2.3 \mathrm{Lha}^{-1}$ & May 1 \\
\hline 1990 & Lasso & No-till & 4.6 $\mathrm{Lha}^{-1}$ & May 1 \\
\hline 1990 & Amiben & No-till & $9.2 \mathrm{Lha}^{-1}$ & May 1 \\
\hline 1992 & Glyphosate & Ridge-till \& No-till & $1.2 \mathrm{Lha}^{-1}$ & April 15 \\
\hline 1992 & $2-4-D$ & Ridge-till \& No-till & $1.8 \mathrm{Lha}^{-1}$ & April 15 \\
\hline 1992 & Lasso & All & $4.6 \mathrm{Lha}^{-1}$ & May 13 \\
\hline 1992 & Pursuit & All & $0.3 \mathrm{Lha}^{-1}$ & May 13 \\
\hline 1994 & Glyphosate & Ridge-till \& No-till & $2.3 \mathrm{Lha}^{-1}$ & April 14 \\
\hline 1994 & $2-4-D$ & Ridge-till \& No-till & $1.2 \mathrm{Lha}^{-1}$ & April 14 \\
\hline 1994 & Glyphosate & Ridge-till \& No-till & $3.5 \mathrm{Lha}^{-1}$ & May 12 \\
\hline 1994 & $2-4-D$ & Ridge-till \& No-till & $1.8 \mathrm{Lha}^{-1}$ & May 12 \\
\hline 1994 & Lasso & All & 4.6 $\mathrm{Lha}^{-1}$ & May 12 \\
\hline 1994 & Pursuit & All & $0.3 \mathrm{Lha}^{-1}$ & May 12 \\
\hline 1994 & Basagran & All & 1.2 $\mathrm{Lha}^{-1}$ & June 12 \\
\hline 1996 & Glyphosate & All & $2.9 \mathrm{Lha}^{-1}$ & June 7 \\
\hline 1996 & $2-4-D$ & All & $0.6 \mathrm{Lha}^{-1}$ & June 7 \\
\hline 1996 & Pursuit & All & $0.3 \mathrm{Lha}^{-1}$ & June 2 \\
\hline 1998 & Glyphosate & All & $2.3 \mathrm{Lha}^{-1}$ & May 18 \\
\hline 2000 & Glyphosate & Ridge-till \& No-till & $1.9 \mathrm{Lha}^{-1}$ & April 29 \\
\hline 2000 & Glyphosate & All & $1.8 \mathrm{Lha}^{-1}$ & June 13 \\
\hline 2002 & Glyphosate & Ridge-till \& No-till & $2.3 \mathrm{Lha}^{-1}$ & May 24 \\
\hline 2002 & Glyphosate & All & $2.3 \mathrm{Lha}^{-1}$ & June 12 \\
\hline 2002 & Glyphosate & All & $2.0 \mathrm{Lha}^{-1}$ & September 6 \\
\hline 2004 & Glyphosate & Ridge-till \& No-till & $2.3 \mathrm{Lha}^{-1}$ & May 20 \\
\hline 2004 & Glyphosate & All & $1.6 \mathrm{Lha}^{-1}$ & June 12 \\
\hline 2004 & Glyphosate & All & $1.8 \mathrm{Lha}^{-1}$ & August 13 \\
\hline 2006 & Dual & Moldboard, Chisel, Disk & $1.8 \mathrm{Lha}^{-1}$ & May 18 \\
\hline 2006 & Glyphosate & All & $2.0 \mathrm{Lha}^{-1}$ & May 26 \\
\hline 2006 & Glyphosate & All & $2.0 \mathrm{Lha}^{-1}$ & June 22 \\
\hline \multicolumn{5}{|c|}{ Continuous corn (CC) } \\
\hline 1980 & Paraquot & No-till & $2.3 \mathrm{Lha}^{-1}$ & April 25 \\
\hline 1980 & Bladex & All & $4.6 \mathrm{Lha}^{-1}$ & April 25 \\
\hline 1980 & Lasso & All & 4.6 $\mathrm{Lha}^{-1}$ & April 25 \\
\hline 1980 & Atrazine + oil & No-till & $1.1 \mathrm{~kg}+2.3 \mathrm{Lha}^{-1}$ & May 20 \\
\hline 1980 & Basagran & Moldboard, Chisel, \& Disk & $2.3 \mathrm{Lha}^{-1}$ & May 23 \\
\hline 1980 & Carbofuran & Ridge-till \& No-till & $1.1 \mathrm{~kg} \mathrm{ha}^{-1}$ & June 17 \\
\hline 1981 & Glyphosate & Ridge-till \& No-till & $2.3 \mathrm{Lha}^{-1}$ & May 7 \\
\hline 1981 & Bladex & All & $4.6 \mathrm{Lha}^{-1}$ & May 7 \\
\hline 1981 & Lasso & All & $4.6 \mathrm{Lha}^{-1}$ & May 7 \\
\hline 1981 & Carbofuran & All & $1.1 \mathrm{~kg} \mathrm{ha}^{-1}$ & June 23 \\
\hline 1982 & Glyphosate & Ridge-till \& No-till & $2.3 \mathrm{Lha}^{-1}$ & May 7 \\
\hline 1982 & Bladex & All & $4.6 \mathrm{Lha}^{-1}$ & May 7 \\
\hline 1982 & Lasso & All & $4.6 \mathrm{Lha}^{-1}$ & May 7 \\
\hline
\end{tabular}


Table A3 (Continued)

\begin{tabular}{|c|c|c|c|c|}
\hline Year & Pesticide trade name ${ }^{\mathrm{a}}$ & Applied to & Rate & Date \\
\hline 1982 & $2-4-D$ & All & $1.2 \mathrm{Lha}^{-1}$ & June 11 \\
\hline 1982 & Carbofuran & All & $1.1 \mathrm{~kg} \mathrm{ha}^{-1}$ & June 24 \\
\hline 1982 & Atrazine \& crop oil & Moldboard and Chisel & $4.6+2.3 \mathrm{Lha}^{-1}$ & June 25 \\
\hline 1983 & Glyphosate & Ridge-till \& No-till & $2.3 \mathrm{Lha}^{-1}$ & May 12 \\
\hline 1983 & Bladex & All & $4.6 \mathrm{Lha}^{-1}$ & May 12 \\
\hline 1983 & Lasso & All & $4.6 \mathrm{Lha}^{-1}$ & May 12 \\
\hline 1983 & $2-4-D$ & All & $1.2 \mathrm{Lha}^{-1}$ & June 9 \\
\hline 1984 & Glyphosate & Ridge-till, No-till, Disk & $2.3 \mathrm{Lha}^{-1}$ & May 18 \\
\hline 1984 & Bladex & All & $4.6 \mathrm{Lha}^{-1}$ & May 18 \\
\hline 1984 & Lasso & All & $4.6 \mathrm{Lha}^{-1}$ & May 18 \\
\hline 1985 & Glyphosate & Ridge-till \& No-till & $2.3 \mathrm{Lha}^{-1}$ & May 1 \\
\hline 1985 & $2-4-D$ & Ridge-till \& No-till & $1.2 \mathrm{Lha}^{-1}$ & May 1 \\
\hline 1985 & Bladex & All & $4.6 \mathrm{Lha}^{-1}$ & May 1 \\
\hline 1985 & Lasso & All & $4.6 \mathrm{Lha}^{-1}$ & May 1 \\
\hline 1986 & Bladex & Ridge-till, No-till, Disk & $5.8 \mathrm{Lha}^{-1}$ & April 24 \\
\hline 1986 & Lasso & Ridge-till, No-till, Disk & 4.6 $\mathrm{Lha}^{-1}$ & April 24 \\
\hline 1986 & Glyphosate & All & $2.3 \mathrm{Lha}^{-1}$ & May 20 \\
\hline 1986 & $2-4-D$ & All & $1.2 \mathrm{Lha}^{-1}$ & May 20 \\
\hline 1986 & Bladex & All & $2.3 \mathrm{Lha}^{-1}$ & May 20 \\
\hline 1987 & (not sprayed) & - & - & - \\
\hline 1988 & Lorsban & All & $10 \mathrm{~kg} \mathrm{ha}^{-1}$ (banded) & May 6 \\
\hline 1988 & Glyphosate & Ridge-till, No-till, Disk & $2.3 \mathrm{Lha}^{-1}$ & May 29 \\
\hline 1988 & Bladex & All & $4.6 \mathrm{Lha}^{-1}$ & May 29 \\
\hline 1988 & Lasso & All & $4.6 \mathrm{Lha}^{-1}$ & May 29 \\
\hline 1989 & Glyphosate & Ridge-till \& No-till & $2.3 \mathrm{Lha}^{-1}$ & May 8 \\
\hline 1989 & 2-4-D + crop oil & Ridge-till \& No-till & $1.2+2.3 \mathrm{Lha}^{-1}$ & May 8 \\
\hline 1989 & Bladex & All & 4. $6 \mathrm{Lha}^{-1}$ & May 8 \\
\hline 1989 & Lasso & All & $4.6 \mathrm{Lha}^{-1}$ & May 8 \\
\hline 1990 & Glyphosate & Ridge-till \& No-till & $2.3 \mathrm{Lha}^{-1}$ & April 30 \\
\hline 1990 & 2-4-D + crop oil & Ridge-till \& No-till & $2.3+2.3 \mathrm{Lha}^{-1}$ & April 30 \\
\hline 1990 & Bladex & All & 4. $6 \mathrm{Lha}^{-1}$ & April 30 \\
\hline 1990 & Lasso & All & 4.6 $\mathrm{Lha}^{-1}$ & April 30 \\
\hline 1991 & Glyphosate & Ridge-till \& No-till & $2.3 \mathrm{Lha}^{-1}$ & May 13 \\
\hline 1991 & 2-4-D + crop oil & Ridge-till \& No-till & $2.3+2.3 \mathrm{Lha}^{-1}$ & May 13 \\
\hline 1991 & Bladex 4L & All & 4. $6 \mathrm{Lha}^{-1}$ & May 13 \\
\hline 1991 & Lasso & All & $4.6 \mathrm{Lha}^{-1}$ & May 13 \\
\hline 1991 & Buctril & (spot sprayed) & $1.2 \mathrm{Lha}^{-1}$ & June 20 \\
\hline 1991 & Atrazine & (spot sprayed) & $1.1 \mathrm{~kg} \mathrm{ha}^{-1}$ & June 20 \\
\hline 1991 & Accent & (spot sprayed) & $49 \mathrm{mLha}^{-1}$ & June 20 \\
\hline 1992 & Glyphosate & Ridge-till \& No-till & $1.2 \mathrm{Lha}^{-1}$ & April 15 \\
\hline 1992 & 2-4-D + crop oil & Ridge-till \& No-till & $1.8+2.3 \mathrm{Lha}^{-1}$ & April 15 \\
\hline 1992 & Bladex & All & 4. $6 \mathrm{Lha}^{-1}$ & May 8 \\
\hline 1992 & Lasso & All & $4.6 \mathrm{Lha}^{-1}$ & May 8 \\
\hline 1993 & Glyphosate & Ridge-till \& No-till & $1.2 \mathrm{Lha}^{-1}$ & April 30 \\
\hline 1993 & $2-4-D+$ crop oil & Ridge-till \& No-till & $1.8+2.3 \mathrm{Lha}^{-1}$ & April 30 \\
\hline 1993 & Lasso & All & 4. $6 \mathrm{Lha}^{-1}$ & May 18 \\
\hline 1993 & Glyphosate & Ridge-till \& No-till & $2.3 \mathrm{Lha}^{-1}$ & May 20 \\
\hline 1993 & $2-4-D+$ crop oil & Ridge-till \& No-till & $1.2+2.3 \mathrm{Lha}^{-1}$ & May 20 \\
\hline 1993 & Pursuit & All & $0.3 \mathrm{Lha}^{-1}$ & June 11 \\
\hline 1994 & Glyphosate & Ridge-till \& No-till & $2.3 \mathrm{Lha}^{-1}$ & April 14 \\
\hline 1994 & $2-4-D$ & Ridge-till \& No-till & 1.2 $\mathrm{Lha}^{-1}$ & April 14 \\
\hline 1994 & Bladex 90 DF & All & $2.5 \mathrm{~kg} \mathrm{ha}^{-1}$ & May 2 \\
\hline 1994 & Lasso & All & $4.6 \mathrm{Lha}^{-1}$ & May 2 \\
\hline 1994 & Glyphosate & Ridge-till \& No-till & $2.3 \mathrm{Lha}^{-1}$ & May 2 \\
\hline 1994 & $2-4-D+$ crop oil & Ridge-till \& No-till & $1.2+2.3 \mathrm{Lha}^{-1}$ & May 2 \\
\hline 1994 & Buctril + crop oil & All & $1.8+2.3 \mathrm{Lha}^{-1}$ & June 3 \\
\hline 1995 & Glyphosate & Ridge-till \& No-till & $2.3 \mathrm{Lha}^{-1}$ & May 12 \\
\hline 1995 & $2-4-D$ & Ridge-till \& No-till & $1.2 \mathrm{Lha}^{-1}$ & May 12 \\
\hline 1995 & Lasso & All & $7.0 \mathrm{Lha}^{-1}$ & May 16 \\
\hline 1995 & Accent & (spot treatment) & $49 \mathrm{mLha}^{-1}$ & June 20 \\
\hline 1995 & Buctril & All & $1.2 \mathrm{Lha}^{-1}$ & June 21 \\
\hline 1996 & Pursuit & All & $0.1 \mathrm{Lha}^{-1}$ & June 11 \\
\hline 1997 & Glyphosate & All & $2.3 \mathrm{Lha}^{-1}$ & May 17 \\
\hline 1997 & Poast Plus & All & $876 \mathrm{mLha}^{-1}$ & June 18 \\
\hline 1997 & Sencor & All & $36 \mathrm{mLha}^{-1}$ & June 20 \\
\hline 1997 & Buctril & All & $1.5 \mathrm{Lha}^{-1}$ & June 20 \\
\hline 1998 & Glyphosate & Ridge-till \& No-till & $2.3 \mathrm{Lha}^{-1}$ & May 19 \\
\hline 1998 & Glyphosate & All & $1.8 \mathrm{Lha}^{-1}$ & June 10 \\
\hline 1999 & Glyphosate & All & $2.3 \mathrm{Lha}^{-1}$ & April 29 \\
\hline 1999 & $2-4-D$ & All & $1.2 \mathrm{Lha}^{-1}$ & April 29 \\
\hline 1999 & Balance & All & $150 \mathrm{~mL} \mathrm{ha}^{-1}$ & April 30 \\
\hline 1999 & Sencor & All & $150 \mathrm{mLha}^{-1}$ & June 7 \\
\hline 1999 & Buctril & All & $0.6 \mathrm{Lha}^{-1}$ & June 7 \\
\hline 2000 & Glyphosate & All & $2.3 \mathrm{Lha}^{-1}$ & May 9 \\
\hline 2000 & $2-4-D$ & All & $0.6 \mathrm{Lha}^{-1}$ & May 9 \\
\hline 2000 & Glyphosate & All & $1.8 \mathrm{Lha}^{-1}$ & May 20 \\
\hline 2000 & Glyphosate & All & $1.8 \mathrm{Lha}^{-1}$ & June 6 \\
\hline
\end{tabular}


Table A3 (Continued)

\begin{tabular}{|c|c|c|c|c|}
\hline Year & Pesticide trade name ${ }^{a}$ & Applied to & Rate & Date \\
\hline 2000 & Glyphosate & All & $2.3 \mathrm{Lha}^{-1}$ & July 7 \\
\hline 2001 & Glyphosate & All & $2.3 \mathrm{Lha}^{-1}$ & May 18 \\
\hline 2001 & Balance & All & $0.1 \mathrm{Lha}^{-1}$ & June 18 \\
\hline 2001 & Glyphosate & All & $1.8 \mathrm{Lha}^{-1}$ & June 19 \\
\hline 2002 & Glyphosate & Ridge-till \& No-till & $1.9 \mathrm{Lha}^{-1}$ & May 5 \\
\hline 2002 & Dual II Magnum & All & $1.8 \mathrm{Lha}^{-1}$ & May 5 \\
\hline 2002 & Liberty & All & $2.0 \mathrm{Lha}^{-1}$ & June 5 \\
\hline 2003 & Glyphosate & Ridge-till \& No-till & $1.9 \mathrm{Lha}^{-1}$ & April 29 \\
\hline 2003 & Dual II Magnum & All & $1.8 \mathrm{Lha}^{-1}$ & April 29 \\
\hline 2004 & Aztec & All & $7.7 \mathrm{~kg} \mathrm{ha}^{-1}$ & April 27 \\
\hline 2004 & Glyphosate & All & $2.3 \mathrm{Lha}^{-1}$ & May 20 \\
\hline 2004 & Glyphosate & All & 1.6 $\mathrm{Lha}^{-1}$ & July 8 \\
\hline 2005 & Lumax & All & $5.8 \mathrm{Lha}^{-1}$ & April 25-May 3 \\
\hline 2005 & Glyphosate & All & $1.6 \mathrm{Lha}^{-1}$ & May 3 \\
\hline 2006 & Dual Magnum & All & $1.8 \mathrm{Lha}^{-1}$ & May 3 \\
\hline 2006 & Glyphosate & Ridge-till \& No-till & $2.0 \mathrm{Lha}^{-1}$ & May 26 \\
\hline 2006 & Glyphosate & All & $2.0 \mathrm{Lha}^{-1}$ & June 7 \\
\hline
\end{tabular}

${ }^{a}$ Chemical names are listed in Table A4.

Table A4

Chemical names for pesticides used in a 30-year tillage system study in central Iowa, U.S.A.

\begin{tabular}{|c|c|}
\hline Trade name & Chemical name \\
\hline Accent & 3-Pyridimecarboxamide,2-[[(4,6-Dimethoxy-pyrimidin-2-yl)amino-carbonyl]aminosulfonyl]-N,N-dimethyl \\
\hline Amiben & 3-Amino-2,5-dichlorobenzoic acid \\
\hline Atrazine & 2-Chloro-4-(ethylamino)-6-(isopropylamino)-s-triazine \\
\hline Balance & 5-Cyclopropyl-1,2-oxazol-4-yl)( $\alpha, \alpha, \alpha$-trifluoro-2-mesyl-p-tolyl)methanone \\
\hline Basagran & 3-(1-Methylethyl)-1H-2,1,3-benzothiadiazin-4-(3H)-one 2,2-dioxide \\
\hline Bladex & 2-[(4-Chloro-6-(ethylamino)-S-triazin-2-yl) amino)]-2-methylpropionitrile \\
\hline Buctril & 3,5-Dibromo-4-hydroxybenzonitrile \\
\hline Carbofuran & 2,3-Dihydro-2,2-dimethyl-7-benzofuranyl methylcarbamate \\
\hline Dual/Dual Magnum & $(R S)$-2-Chloro- $N$-(2-ethyl-6-methyl-phenyl)- $N$-(1-methoxypropan-2-yl)acetamide \\
\hline Glyphosate & $\mathrm{N}-($ Phosphonomethyl) glycine \\
\hline Hoelon & Diclofop-methyl: methyl 2-[4-(2,4-dichlorophenoxy) phenoxy]propanoate \\
\hline Lasso & 2-Chloro-2'-6'-diethyl-N-(methoxymethyl)-acetanilide \\
\hline Liberty & 2-Amino-4-(hydroxymethylphosphinyl)butanoic acid \\
\hline Lorsban & O,O-Diethyl 0 -3,5,6-trichloropyridin-2-yl phosphorothioate \\
\hline Lumax & 2-Chloro-4-ethylamino-6-isopropylamino-s-triazine \\
\hline Paraquot & $N, N^{\prime}$-Dimethyl-4,4'-bipyridinium dichloride \\
\hline Poast Plus & 2-[1-(Ethoxyimino)butyl]-5-[2-(ethylthio)propyl]-3-hydroxy-2-cycloxexen-1-one \\
\hline Pursuit & (+)-2-4,5-Dihydro-4-methyl-4-(1-methylethyl)-5-oxo-1H-imidazol-2-y1|-5-ethyl-3-pyridinecarboxylic acid \\
\hline Sencor & 4-Amino-6-(1,1-dimethylethyl)-3-(methylthio)-1,2,4-triazin-5(4H)-one \\
\hline Sevin (Carbaryl) & 1-Naphthyl methylcarbamate \\
\hline $2-4-\mathrm{D}$ & 2,4-Dichlorophenoxyacetic acid \\
\hline
\end{tabular}

Table A5

Phase one $^{\mathrm{a}}$ (1976-1980), two ${ }^{\mathrm{b}}$ (1988-2002) and three (2003-2006) crop yield response to long-term tillage treatments on glacial till soils in Central Iowa, U.S.A.

\begin{tabular}{|c|c|c|c|c|c|c|c|}
\hline Year & Moldboard plow (Mg ha $\left.{ }^{-1}\right)$ & Chisel plow & Spring disk & Ridge-till & No-till & Seasonal average & $\begin{array}{l}\text { NASS boone } \\
\text { county average }\end{array}$ \\
\hline \multicolumn{8}{|c|}{ Phase 1-Establishment (rotated corn) } \\
\hline 1976 & 7.6 & 7.5 & 7.3 & 7.3 & 7.3 & 7.4 & 6.4 \\
\hline 1977 & 4.2 & 4.7 & 4.7 & 4.7 & 4.7 & 4.6 & 2.1 \\
\hline 1978 & 10.8 & 10.5 & 10.7 & 10.2 & 10.4 & 10.5 & 7.6 \\
\hline 1979 & 10.8 & 10.5 & 10.6 & 10.1 & 9.8 & 10.4 & 8.9 \\
\hline 1980 & 10.1 & 10.2 & 9.7 & 10.1 & 10.3 & 10.1 & 7.4 \\
\hline Average & 8.7 & 8.7 & 8.6 & 8.5 & 8.5 & 8.6 & 6.5 \\
\hline \multicolumn{8}{|c|}{ Phase 1 Tillage $\operatorname{LSD}_{(0.05)}$ for corn $=\mathrm{NS}$} \\
\hline \multicolumn{8}{|c|}{ Phase 1-Establishment (rotated soybean) } \\
\hline 1976 & 1.8 & 1.8 & 2.0 & 1.9 & 1.7 & 1.8 & 2.1 \\
\hline 1977 & 1.4 & 1.7 & 2.1 & 1.7 & 2.1 & 1.8 & 1.6 \\
\hline 1978 & 3.4 & 3.2 & 3.2 & 3.1 & 3.2 & 3.2 & 2.9 \\
\hline 1979 & 3.3 & 3.3 & 3.4 & 3.2 & 3.4 & 3.3 & 2.7 \\
\hline 1980 & 3.5 & 3.3 & 3.3 & 3.3 & 3.4 & 3.4 & 2.9 \\
\hline Average & 2.7 & 2.7 & 2.8 & 2.6 & 2.7 & 2.7 & 2.4 \\
\hline \multicolumn{8}{|c|}{ Phase 1 Tillage $\operatorname{LSD}_{(0.05)}$ for soybean $=$ NS } \\
\hline \multicolumn{8}{|c|}{ Phase 2-Maintenance (continuous corn) } \\
\hline 1988 & 5.9 & 5.5 & 4.6 & 4.8 & 5.7 & 5.3 & 5.4 \\
\hline 1989 & 8.7 & 8.5 & 7.9 & 7.1 & 8.1 & 8.1 & 8.2 \\
\hline 1990 & 9.5 & 8.9 & 8.5 & 6.8 & 8.3 & 8.4 & 7.4 \\
\hline 1991 & 9.8 & 9.0 & 8.6 & 8.4 & 8.8 & 8.9 & 7.7 \\
\hline 1992 & 10.3 & 7.9 & 7.5 & 8.3 & 8.9 & 8.6 & 10.3 \\
\hline
\end{tabular}


Table A5 (Continued)

\begin{tabular}{|c|c|c|c|c|c|c|c|}
\hline Year & Moldboard plow $\left(\mathrm{Mg} \mathrm{ha}^{-1}\right)$ & Chisel plow & Spring disk & Ridge-till & No-till & Seasonal average & $\begin{array}{l}\text { NASS boone } \\
\text { county average }\end{array}$ \\
\hline 1993 & 5.0 & 4.5 & 4.3 & 3.3 & 4.7 & 4.4 & 5.3 \\
\hline 1994 & 10.6 & 9.7 & 9.4 & 8.2 & 8.7 & 9.3 & 10.4 \\
\hline 1995 & 9.6 & 8.4 & 6.7 & 6.3 & 6.2 & 7.4 & 9.4 \\
\hline 1996 & 6.9 & 4.6 & 4.6 & 4.2 & 3.9 & 4.8 & 9.3 \\
\hline 1997 & 7.1 & 6.6 & 6.8 & 6.5 & 6.5 & 6.7 & 9.4 \\
\hline 1998 & 8.6 & 8.3 & 7.4 & 7.3 & 8.3 & 8.0 & 9.2 \\
\hline 1999 & 10.8 & 9.8 & 9.0 & 8.2 & 9.0 & 9.3 & 9.8 \\
\hline 2000 & 8.5 & 8.4 & 7.9 & 6.9 & 6.6 & 8.2 & 9.7 \\
\hline 2001 & 6.8 & 6.3 & 6.2 & 6.9 & 6.6 & 6.6 & 9.7 \\
\hline 2002 & 9.3 & 8.6 & 8.6 & 8.3 & 8.3 & 8.6 & 10.7 \\
\hline Average & 8.5 & 7.7 & 7.2 & 6.8 & 7.4 & 7.5 & 8.8 \\
\hline \multicolumn{8}{|c|}{ Phase 2 Tillage $\operatorname{LSD}_{(0.1)}$ for continuous corn $=0.3$} \\
\hline \multicolumn{8}{|c|}{ Phase 2-Maintenance (rotated corn) } \\
\hline 1989 & 8.8 & 8.5 & 8.6 & 9.2 & 9.0 & 8.8 & 8.2 \\
\hline 1991 & 9.7 & 9.8 & 9.4 & 9.4 & 9.4 & 9.6 & 7.7 \\
\hline 1993 & 7.3 & 7.6 & 7.4 & 6.9 & 6.7 & 7.2 & 5.3 \\
\hline 1995 & 8.6 & 8.2 & 8.0 & 7.4 & 7.3 & 7.9 & 9.4 \\
\hline 1997 & 9.0 & 8.6 & 8.7 & 8.6 & 8.1 & 8.6 & 9.4 \\
\hline 1999 & 11.0 & 10.8 & 10.8 & 10.4 & 10.1 & 10.6 & 9.8 \\
\hline 2001 & 9.2 & 8.7 & 8.9 & 8.8 & 7.6 & 8.6 & 9.7 \\
\hline Average & 9.1 & 8.9 & 8.8 & 8.7 & 8.3 & 8.8 & 8.5 \\
\hline \multicolumn{8}{|c|}{ Phase 2 Tillage $\operatorname{LSD}_{(0.1)}$ for rotated corn $=0.2$} \\
\hline \multicolumn{8}{|c|}{ Phase 2-Maintenance (rotated soybean) } \\
\hline 1988 & 1.80 & 1.55 & 1.03 & - & - & 1.46 & 1.6 \\
\hline 1990 & 3.48 & 3.15 & 2.98 & 3.30 & 3.32 & 3.24 & 2.7 \\
\hline 1992 & 3.24 & 2.71 & 2.50 & 2.58 & 2.47 & 4.04 & 3.1 \\
\hline 1994 & 4.26 & 3.99 & 4.02 & 4.02 & 3.82 & 2.70 & 3.5 \\
\hline 1996 & 4.18 & 4.05 & 4.02 & 3.98 & 3.97 & 4.02 & 3.1 \\
\hline 1998 & 3.55 & 3.38 & 3.50 & 3.46 & 3.44 & 3.46 & 3.2 \\
\hline 2000 & 3.10 & 2.84 & 2.97 & 2.82 & 2.80 & 2.91 & 2.7 \\
\hline 2002 & 3.17 & 3.53 & 3.39 & 3.35 & 3.29 & 3.35 & 3.2 \\
\hline Average & 3.34 & 3.15 & 3.05 & 3.36 & 3.30 & 3.24 & 2.9 \\
\hline \multicolumn{8}{|c|}{ Phase 2 Tillage $\operatorname{LSD}_{(0.1)}$ for rotated soybean $=0.09$} \\
\hline \multicolumn{8}{|c|}{ Phase 3-Intensification and Recovery (continuous corn) } \\
\hline 2003 & 9.7 & 10.1 & 9.3 & 0.6 & 9.7 & 9.7 & 10.7 \\
\hline 2004 & 11.4 & 11.1 & 10.9 & 11.0 & 10.7 & 11.0 & 12.1 \\
\hline 2005 & 10.2 & 9.6 & 9.6 & 10.0 & 9.7 & 9.8 & 12.1 \\
\hline 2006 & 10.6 & 10.1 & 10.0 & 9.7 & 9.6 & 10.0 & 10.8 \\
\hline Average & 10.5 & 10.2 & 10.0 & 10.1 & 9.9 & 10.1 & 11.4 \\
\hline \multicolumn{8}{|c|}{ Phase 3 Tillage $\operatorname{LSD}_{(0.1)}$ for continuous corn $=0.2$} \\
\hline \multicolumn{8}{|c|}{ Phase 3-Intensification and Recovery (rotated corn) } \\
\hline 2003 & 11.0 & 11.2 & 11.2 & 11.2 & 11.2 & 11.2 & 10.7 \\
\hline 2005 & 12.7 & 12.2 & 12.4 & 11.6 & 11.8 & 12.1 & 12.1 \\
\hline Average & 11.8 & 11.7 & 11.8 & 11.4 & 11.5 & 11.6 & 11.4 \\
\hline \multicolumn{8}{|c|}{ Phase 3 Tillage $\operatorname{LSD}_{(0.1)}$ for rotated corn $=0.2$} \\
\hline \multicolumn{8}{|c|}{ Phase 3-Intensification and Recovery (rotated soybean) } \\
\hline 2004 & 3.64 & 3.55 & 3.28 & 3.44 & 3.45 & 3.48 & 3.5 \\
\hline 2006 & 3.45 & 3.44 & 3.43 & 3.33 & 3.38 & 3.40 & 3.4 \\
\hline Average & 3.54 & 3.49 & 3.36 & 3.40 & 3.42 & 3.44 & 3.4 \\
\hline \multicolumn{8}{|c|}{ Phase 3 Tillage $\operatorname{LSD}_{(0.1)}$ for rotated soybean $=0.12$} \\
\hline
\end{tabular}

a Phase one yields are reprinted from Erbach, D.C. 1982.

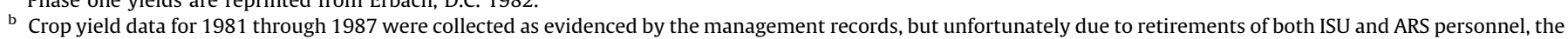
data have been lost.

Table A6

Long-term tillage and crop rotation effects on grain moisture $\left(\mathrm{g} \mathrm{kg}^{-1}\right)$.

\begin{tabular}{|c|c|c|c|c|c|c|}
\hline Year & Moldboard plow & Chisel plow & Disk & Ridge-till & No-Till & Average \\
\hline \multicolumn{7}{|c|}{ Phase 2-Maintenance (continuous corn) } \\
\hline 1988 & 156 & 158 & 157 & 157 & 158 & 157 \\
\hline 1989 & 159 & 164 & 164 & 166 & 174 & 165 \\
\hline 1990 & 179 & 188 & 180 & 186 & 182 & 183 \\
\hline 1991 & 174 & 167 & 171 & 171 & 174 & 171 \\
\hline 1992 & 203 & 213 & 225 & 200 & 204 & 209 \\
\hline 1993 & 206 & 217 & 214 & 219 & 220 & 215 \\
\hline 1994 & 168 & 168 & 170 & 170 & 168 & 169 \\
\hline 1995 & 151 & 152 & 154 & 153 & 152 & 152 \\
\hline 1996 & 172 & 169 & 169 & 166 & 162 & 168 \\
\hline 1997 & 152 & 160 & 162 & 160 & 149 & 157 \\
\hline 1998 & 151 & 153 & 158 & 158 & 151 & 154 \\
\hline 1999 & 147 & 146 & 150 & 149 & 149 & 148 \\
\hline 2000 & 138 & 138 & 143 & 137 & 137 & 139 \\
\hline
\end{tabular}


Table A6 (Continued)

\begin{tabular}{|c|c|c|c|c|c|c|}
\hline Year & Moldboard plow & Chisel plow & Disk & Ridge-till & No-Till & Average \\
\hline 2001 & 160 & 157 & 158 & 160 & 156 & 158 \\
\hline 2002 & 167 & 168 & 168 & 168 & 166 & 168 \\
\hline Average & 165 & 168 & 170 & 168 & 167 & 168 \\
\hline \multicolumn{7}{|c|}{ Phase 3 Tillage $\operatorname{LSD}_{(0.1)}$ for continuous corn $=2$} \\
\hline \multicolumn{7}{|c|}{ Phase 2-Maintenance (rotated corn) } \\
\hline 1989 & 173 & 173 & 176 & 172 & 187 & 176 \\
\hline 1991 & 169 & 173 & 171 & 171 & 171 & 171 \\
\hline 1993 & 230 & 223 & 226 & 234 & 228 & 228 \\
\hline 1995 & 167 & 168 & 168 & 166 & 160 & 168 \\
\hline 1997 & 136 & 134 & 136 & 141 & 136 & 137 \\
\hline 1999 & 144 & 144 & 144 & 145 & 146 & 144 \\
\hline 2001 & 162 & 162 & 164 & 161 & 165 & 163 \\
\hline Average & 169 & 168 & 169 & 170 & 170 & 169 \\
\hline \multicolumn{7}{|c|}{ Phase 3 Tillage $\operatorname{LSD}_{(0.1)}$ for rotated corn $=$ NS } \\
\hline \multicolumn{7}{|c|}{ Phase 2-Maintenance (rotated soybean) } \\
\hline 1988 & 97 & 103 & 107 & - & - & 102 \\
\hline 1990 & 92 & 101 & 102 & 85 & 89 & 94 \\
\hline 1992 & 130 & 121 & 126 & 118 & 118 & 122 \\
\hline 1994 & 133 & 126 & 131 & 128 & 126 & 129 \\
\hline 1996 & 119 & 119 & 120 & 113 & 120 & 118 \\
\hline 1998 & 116 & 114 & 116 & 117 & 113 & 115 \\
\hline 2000 & 90 & 90 & 89 & 87 & 90 & 89 \\
\hline 2002 & 108 & 106 & 107 & 107 & 106 & 107 \\
\hline Average & 110 & 110 & 112 & 108 & 109 & 110 \\
\hline \multicolumn{7}{|c|}{ Phase 3 Tillage $\operatorname{LSD}_{(0.1)}$ for rotated soybean $=3$} \\
\hline \multicolumn{7}{|c|}{ Phase 3-Intensification and Recovery (continuous corn) } \\
\hline 2003 & 146 & 148 & 146 & 147 & 149 & 147 \\
\hline 2004 & 199 & 196 & 193 & 200 & 202 & 198 \\
\hline 2005 & 162 & 164 & 164 & 153 & 154 & 159 \\
\hline 2006 & 174 & 176 & 177 & 177 & 179 & 176 \\
\hline Average & 170 & 171 & 170 & 169 & 171 & 170 \\
\hline \multicolumn{7}{|c|}{ Phase 4 Tillage $\operatorname{LSD}_{(0.1)}$ for continuous corn $=\mathrm{NS}$} \\
\hline \multicolumn{7}{|c|}{ Phase 3-Intensification and Recovery (rotated corn) } \\
\hline 2003 & 160 & 160 & 161 & 160 & 161 & 160 \\
\hline 2005 & 159 & 156 & 158 & 162 & 161 & 159 \\
\hline Average & 159 & 158 & 160 & 161 & 161 & 160 \\
\hline \multicolumn{7}{|c|}{ Phase 4 Tillage $\operatorname{LSD}_{(0.1)}$ for rotated corn $=1$} \\
\hline \multicolumn{7}{|c|}{ Phase 3-Intensification and Recovery (rotated soybean) } \\
\hline 2004 & - & - & - & - & - & - \\
\hline 2006 & 107 & 106 & 108 & 107 & 106 & 106 \\
\hline
\end{tabular}

Table A7

Profile ANOVA results for selected soil quality indicators measured in autumn 2005 at the long-term site used for tillage system comparisons in central Iowa, U.S.A.

\begin{tabular}{|c|c|c|c|c|}
\hline Indicator & Tillage & Map Unit (MU) & Rep & Tillage*MU \\
\hline \multicolumn{5}{|l|}{ Probability $>F$} \\
\hline \multicolumn{5}{|l|}{$0-0.15 \mathrm{~m}$} \\
\hline Bulk density (BD) & 0.3323 & 0.1747 & 0.4597 & 0.0936 \\
\hline Nitrate $\mathrm{N}\left(\mathrm{NO}_{3}-\mathrm{N}\right)$ & 0.0049 & 0.0530 & 0.4060 & 0.4669 \\
\hline Ammonium $\mathrm{N}\left(\mathrm{NH}_{4}-\mathrm{N}\right)$ & 0.3747 & 0.6297 & 0.0181 & 0.3022 \\
\hline Electrical Conductivity (EC) & 0.2410 & $<0.0001$ & 0.0032 & 0.3010 \\
\hline $\mathrm{pH}$ & 0.4101 & 0.3010 & 0.0723 & 0.2602 \\
\hline Mehlich III Extractable P & 0.0126 & 0.0018 & 0.4065 & 0.3060 \\
\hline Mehlich III Extractable K & 0.0458 & 0.1275 & 0.0285 & 0.6249 \\
\hline Mehlich III Extractable Ca & 0.4653 & $<0.0001$ & 0.0080 & 0.4564 \\
\hline Mehlich III Extractable Mg & 0.6461 & $<0.0001$ & $<0.0001$ & 0.0190 \\
\hline DTPA Extractable Cu & 0.6333 & 0.2078 & 0.1303 & 0.0452 \\
\hline DTPA Extractable Fe & 0.1524 & $<0.0001$ & 0.2459 & 0.0295 \\
\hline DTPA Extractable Mn & 0.0601 & 0.8346 & 0.0500 & 0.1437 \\
\hline DTPA Extractable Zn & 0.9365 & 0.1152 & 0.0982 & 0.1693 \\
\hline \multicolumn{5}{|l|}{$0.15-0.30 \mathrm{~m}$} \\
\hline Bulk density (BD) & 0.0495 & 0.0143 & 0.1621 & 0.9095 \\
\hline Nitrate $\mathrm{N}\left(\mathrm{NO}_{3}-\mathrm{N}\right)$ & $<0.0001$ & 0.6143 & 0.9399 & 0.9128 \\
\hline Ammonium N $\left(\mathrm{NH}_{4}-\mathrm{N}\right)$ & 0.3231 & 0.7807 & 0.3060 & 0.4025 \\
\hline Electrical Conductivity (EC) & 0.3381 & $<0.0001$ & 0.0341 & 0.1624 \\
\hline $\mathrm{pH}$ & 0.0085 & 0.8665 & 0.0045 & 0.9416 \\
\hline Mehlich III Extractable P & 0.0410 & 0.2709 & 0.9993 & 0.5473 \\
\hline Mehlich III Extractable K & 0.2468 & 0.0033 & 0.3259 & 0.7707 \\
\hline Mehlich III Extractable Ca & 0.9885 & $<0.0001$ & 0.0055 & 0.2115 \\
\hline Mehlich III Extractable Mg & 0.7051 & $<0.0001$ & 0.0053 & 0.1815 \\
\hline DTPA Extractable $\mathrm{Cu}$ & 0.9248 & 0.4472 & 0.5290 & 0.7641 \\
\hline
\end{tabular}


Table A7 (Continued)

\begin{tabular}{|c|c|c|c|c|}
\hline Indicator & Tillage & Map Unit (MU) & Rep & Tillage* MU \\
\hline DTPA Extractable Fe & 0.1597 & 0.0401 & 0.0029 & 0.1362 \\
\hline DTPA Extractable Mn & 0.1597 & 0.0051 & 0.1454 & 0.7327 \\
\hline DTPA Extractable Zn & 0.9482 & 0.1097 & 0.6302 & 0.8225 \\
\hline \multicolumn{5}{|l|}{$0.30-0.60 \mathrm{~m}$} \\
\hline Bulk density (BD) & 0.4754 & $<0.0001$ & 0.0522 & 0.2101 \\
\hline Nitrate $\mathrm{N}\left(\mathrm{NO}_{3}-\mathrm{N}\right)$ & 0.0024 & 0.3849 & 0.5072 & 0.3075 \\
\hline Ammonium $\mathrm{N}\left(\mathrm{NH}_{4}-\mathrm{N}\right)$ & 0.1549 & 0.9402 & 0.3169 & 0.3064 \\
\hline Electrical Conductivity (EC) & 0.9436 & $<0.0001$ & 0.0653 & 0.2009 \\
\hline $\mathrm{pH}$ & 0.0389 & 0.0631 & 0.0007 & 0.9999 \\
\hline Mehlich III Extractable P & 0.0153 & 0.0239 & 0.4889 & 0.0518 \\
\hline Mehlich III Extractable K & 0.8207 & 0.0031 & 0.7458 & 0.1305 \\
\hline Mehlich III Extractable Ca & 0.9575 & $<0.0001$ & 0.0691 & 0.7605 \\
\hline Mehlich III Extractable Mg & 0.8866 & $<0.0001$ & 0.0893 & 0.6125 \\
\hline DTPA Extractable Cu & 0.3428 & 0.2333 & 0.9578 & 0.0216 \\
\hline DTPA Extractable Fe & 0.0678 & 0.0005 & 0.0397 & 0.0265 \\
\hline DTPA Extractable Mn & 0.9333 & 0.0595 & 0.2632 & 0.2676 \\
\hline DTPA Extractable $\mathrm{Zn}$ & 0.2138 & 0.0515 & 0.9804 & 0.0873 \\
\hline \multicolumn{5}{|l|}{$0.60-0.90 \mathrm{~m}$} \\
\hline Bulk density (BD) & 0.8480 & 0.1481 & 0.2711 & 0.1402 \\
\hline Nitrate $\mathrm{N}\left(\mathrm{NO}_{3}-\mathrm{N}\right)$ & 0.7976 & 0.2529 & 0.4672 & 0.0788 \\
\hline Ammonium $\mathrm{N}\left(\mathrm{NH}_{4}-\mathrm{N}\right)$ & 0.1177 & 0.7769 & 0.0026 & 0.7774 \\
\hline Electrical Conductivity (EC) & 0.3655 & 0.0066 & 0.1403 & 0.8840 \\
\hline $\mathrm{pH}$ & 0.0984 & 0.6889 & 0.0620 & 0.2792 \\
\hline Mehlich III Extractable P & 0.1420 & 0.4697 & 0.2554 & 0.0984 \\
\hline Mehlich III Extractable K & 0.3698 & 0.1146 & 0.9235 & 0.8923 \\
\hline Mehlich III Extractable Ca & 0.0145 & 0.9937 & 0.0441 & 0.9935 \\
\hline Mehlich III Extractable Mg & 0.6438 & 0.0003 & 0.2227 & 0.5887 \\
\hline DTPA Extractable $\mathrm{Cu}$ & 0.5369 & 0.8206 & 0.4366 & 0.0012 \\
\hline DTPA Extractable Fe & 0.0671 & 0.0058 & 0.6307 & 0.4864 \\
\hline DTPA Extractable Mn & 0.9686 & 0.0153 & 0.0311 & 0.0575 \\
\hline DTPA Extractable Zn & 0.3877 & 0.7453 & 0.5529 & 0.0049 \\
\hline
\end{tabular}

\section{References}

Colvin, T.S., Meek, D.W., Cook, J.D., Baker, J.L., Cruse, R.M., 2001. Analysis of long term experiment record. American Society of Agricultural Engineers (ASAE) Meeting Presentation No. 01-AETC-01. ASAE, St. Joseph, MI.

Coughenour, C.M., Chamala, S., 2000. Conservation Tillage and Croppping Innovation: Constructing the New Culture of Agriculture. Iowa State University Press, Ames, IA 360 pp.

Duffy, M.D., 2012. Estimated Costs of Crop Production in Iowa-2012. FM-1712 (Revised January 2012) Iowa State University Extension and Outreach, Ames, IA Available on-line at: https://store.extension.iastate.edu/ItemDetail.aspx? ProductID=1793.

Duffy, M.D., 2012. Historical Costs of Crop Production. Ag Decision Maker. File A121. (Revised April 2012) Iowa State University Extension and Outreach, Ames, IA. Available on-line at: http://www.extension.iastate.edu/agdm.

Eckert, D.J., 1987. Soil test interpretations: basic cation saturation ratios and sufficiency levels. In: Brown, J.R. (Ed.), Soil Testing: Sampling, Correlation, Calibration, and Interpretation. Soil Science Society of America (SSSA) Specia Publication No. 21. SSSA, Madison, WI. pp. 53-64.

Erbach, D.C., 1982. Tillage for continuous corn and corn-soybean rotation. Transactions of the American Society of Agricultural Engineering (ASAE) 25, 906-918.

Holanda, F.S.R., Mengel, D.B., Paula, M.B., Carvaho, J.G., Bertoni, J.C., 1998. Influence of crop rotations and tillage systems on phosphorus and potassium stratification and root distribution in the soil profile. Communications in Soil Science and Plant Analysis 29, 2383-2394.

Karlen, D.L., Varvel, G.E., Bullock, D.G., Cruse, R.M., 1994. Crop rotations for the 21st century. Advances in Agronomy 53, 1-45.

Karlen, D.L., Kohler, K.A., Laird, D.A., Thompson, R.L., Buhler, D.D., 2002. Soil-tes dynamics throughout a five-year Thompson Farm rotation in Iowa. American Journal of Alternative Agriculture 17, 9-17.

Karlen, D.L., Kovar, J.L., 2005. Is $\mathrm{K}$ the Cinderella nutrient for reduced tillage systems? Fluid Journal 13 (4), 8-11.

Karlen, D.L., Hurley, E.G., Andrews, S.S., Cambardella, C.A., Meek, D.W., Duffy, M.D., Mallarino, A.P., 2006. Crop rotation effects on soil quality at three northern corn/soybean belt locations. Agronomy Journal 98, 484-495.

Karlen, D.L., Andrews, S.S., Wienhold, B.J., Zobeck, T.M., 2008. Soil quality assessment: past, present and future. Journal of Integrated Biosciences 6 (1), 3-14.

Karlen, D.L., Birrell, S.J., Hess, J.R., 2011. A five-year assessment of corn stover harvest in Central Iowa, USA. Soil \& Tillage Research 115-116, 47-55.

Mehlich, A., 1984. Mehlich 3 soil test extractant: a modification of Mehlich 2 extractant. Communications in Soil Science and Plant Analysis 15, 1409-1416.

Mills, H.A., Jones, Jr., J.B., 1996. Plant Analysis Handbook II. MicroMacro Publishing, Athens, GA.
Rehm, G.W., Fixen, P.E., 1990. Potassium deficiency in a corn-a common ridge-till problem. Better Crops Plant Food 73, 6-8.

Richter, D., deB. Jr., Hofmockel, M., Callaham Jr., M.A., Powlson, D.S., Smith, P., 2007. Long-term soil experiments: keys to managing earth's rapidly changing ecosystems. Soil Science Society of America Journal 71, 266-279.

SAS Inst., 1990. SAS/STAT User's Guide. Version 6. 4th Ed. SAS Inst., Cary, NC.

Sawyer, J.E., Mallarino, A.P., Killorn, R., Barnhart, S.K., 2011. A General Guide for Crop Nutrient and Limestone Recommendations in Iowa. PM-1688. Iowa State University Extension, Ames, IA. Available online at: http://www.extension.iastate.edu/Publications/PM1688.pdf.

Shi, X.H., Yang, X.M., Drury, C.F., Reynolds, W.D., McLaughlin, N.B., Zhang, X.P., 2012. Impact of ridge tillage on soil organic carbon and selected physical properties of a clay loam in southwestern Ontario. Soil \& Tillage Research 120, $1-7$.

Six, J., Ogle, S.M., Breidt, F.J., Conant, R.T., Mosier, A.R., Paustian, K., 2004. The potential to mitigate global warming with no-tillage management is only realized when practiced in the long term. Global Change Biology 10, $155-160$.

Soil Survey Staff, Natural Resources Conservation Service, United States Department of Agriculture, 2010. Official Soil Series Descriptions. Available online at: http:// soils.usda.gov/technical/classification/osd/index.html.

Stott, D.E., Cambardella, C.A., Tomer, M.D., Karlen, D.L., Wolf, R., 2011. A soil quality assessment within the Iowa River South Fork Watershed. Soil Science Society of America Journal 75, 2271-2282.

Toliver, D.K., Larson, J.A., Roberts, R.K., English, B.C., De La Torre Ugarte, D.G., West, T.O., 2012. Effects of not-till on yields as influenced by crop and environmental factors. Agronomy Journal 104, 530-541.

USDA-National Agricultural Statistics Service (NASS), 2012. Quick Stats [Online]. Washington, D.C. http://www.nass.usda.gov/Data_and_Statistics/Quick_Stats/ index.asp (accessed May 17, 2012).

USDA-Soil Conservation Service (SCS), 1981. Soil Survey of Boone County, Iowa. USDA-NRCS, Washington, D.C., 200 pp.

Watson, M.E., Brown, J.R., 1998. pH and lime requirement. In: Brown, J.R. (Ed.), Recommended Chemical Soil Test Procedures for the North Central Region, NCR Publ. 221 (revised). Missouri Agric. Expt. Stn., Columbia, MO. pp. 13-16.

Whitney, D.A., 1998. Soil salinity. In: Brown, J.R. (Ed.), Recommended Chemical Soil Test Procedures for the North Central Region, NCR Publ. 221 (revised). Missouri Agric. Expt. Stn., Columbia, MO. pp. 59-60.

Whitney, D.A., 1998. Micronutrients: zinc, iron, manganese and copper. In: Brown, J.R. (Ed.), Recommended Chemical Soil Test Procedures for the North Central Region, NCR Publ. 221 (revised). Missouri Agric. Expt. Stn., Columbia, MO. pp. 41-44. 